Article

\title{
Sustainable Urban Development Strategic Initiatives
}

\author{
Margarita Panteleeva and Svetlana Borozdina *(D)
}

Department of Economics and Management in Construction, Moscow State University of Civil Engineering, 26, Yaroslavskoye Shosse, 129337 Moscow, Russia; PanteleevaMS@mgsu.ru

* Correspondence: BorozdinaSM@mgsu.ru; Tel.: +7-905-585-17-34

Citation: Panteleeva, M.; Borozdina, S. Sustainable Urban Development Strategic Initiatives. Sustainability 2022, 14, 37. https://doi.org /10.3390/su14010037

Academic Editors: Pierfrancesco De Paola, Francesco Tajani,

Marco Locurcio and Felicia Di Liddo

Received: 23 November 2021

Accepted: 17 December 2021

Published: 21 December 2021

Publisher's Note: MDPI stays neutral with regard to jurisdictional claims in published maps and institutional affiliations.

Copyright: (C) 2021 by the authors. Licensee MDPI, Basel, Switzerland. This article is an open access article distributed under the terms and conditions of the Creative Commons Attribution (CC BY) license (https:// creativecommons.org/licenses/by/ $4.0 /)$.

\begin{abstract}
In order to ensure the implementation of the "Strategy for the Development of the Construction Industry of the Russian Federation until 2030" and the implementation of the UN resolution on sustainable development, there is a need to develop new strategic management initiatives. They should allow authorities to make inter-city comparisons, considering specific cities and their objects against the background of others undergoing similar development processes. In this article, the authors propose strategic initiatives for the management of urban facilities. In particular, the authors' approach to the assessment of the sustainable development of housing and communal service facilities in the city is proposed. According to the authors, the housing and communal city service objects mean capital construction objects in different forms of reproduction. Moreover, the article examines both residential buildings and structures, and utility networks. The authors' approach consists in the constant assessment of the city's housing and communal service facilities at different stages of their operation. For this, the authors use several types of analysis: ex post analysis, ex ante analysis, and foresight analysis. For each type of analysis, the authors form a set of assessment indicators and indicate the period of the analysis. The result of the study is the development of an indicator for the assessment of the level of sustainable development of housing and communal service facilities in the city, and a roadmap for their development strategy. The roadmap is formed considering the introduction of modern end-to-end technologies and digital tools into the work of state bodies. The proposed approach, on the one hand, considers the internal complexity and heterogeneity of the city's housing and communal service facilities. On the other hand, it is a simple tool for the making of effective management decisions by power structures, as it uses data which are available on a regular basis.
\end{abstract}

Keywords: housing and communal services; development; urban facilities; road map; strategy; end-to-end technologies; artificial intelligence

\section{Introduction}

Currently, half of the world's population lives in cities and consumes three quarters of the world's resources [1]. Many of the modern capitals that play a dominant role in the life of individual countries can be called cities of global importance, due to their decisive contribution to the political, economic and social life of not only individual countries but the whole world.

The urban population growth projected over the coming decades is expected to lead to an increase in urban problems that are interconnected and complex.

Among the most important, promising problems are the problems of urban infrastructure, covering the main critical sectors of life: transport, energy, digitalization, waste, housing, and communal services. The relevance and complexity of solving problems related to the creation of sustainable urban infrastructure is often due to the complex nature of the organizational and economic relationships that arise during the functioning of its various elements [2].

"Sustainable development" is interpreted today as development that "meets the needs of the present without compromising the ability of future generations to meet their own 
needs." [3]. It should be noted that the combination of "sustainable development" was criticized by several scientists [4] as being contradictory in nature. Nevertheless, this term has become entrenched in political and scientific use to denote the balanced growth and development of humanity in interaction with the environment. In the resolution of the UN General Assembly No. A70/L.1 "Transforming our world: the 2030 Agenda for Sustainable Development" dated 25 September 2015, 17 sustainable development goals were identified, covering various aspects [1]. Among them, goal number 11 stands out: "To make cities and towns inclusive, safe and sustainable." To this end, the task of creating a stable living environment for the Russian Federation, set at the global level, began to be solved immediately. In December 2016, Rosstat became a member of the Interdepartmental Working Group under the Presidential Administration of the Russian Federation on Climate Change and Sustainable Development (IWG). Under the IWG, chaired by Rosstat, a Group of Experts on Information and Statistical Support for Monitoring Sustainable Development Goals was created. As a result, systematic work is underway in Russia to create conditions for the improvement of the quality of life and housing conditions of citizens. In this regard, we will consider the housing and communal service industry, which today occupies a leading role in the formation of a sustainable urban environment through the quality of the provided housing and communal services, and the management of housing and communal service facilities.

The analysis of the housing and communal services industry for the period from 1990 to 2020 showed that it does not meet the needs of the population in the main aspects [5]. The results of a study conducted by RIA NOVOSTI on the eve of the Day of Housing and Utilities Workers in 2020 states that the quality of housing services in Russia is not acceptable for $73 \%$ of respondents. Every fourth citizen of the Russian Federation (24\%) assessed the activities of this sphere satisfactorily, and only $3 \%$ of the citizens had no complaints about housing and communal services, and were absolutely satisfied with its services [6-9].

However, when analyzing the housing and communal service industry, special attention should be paid to housing and communal services, in particular residential real estate, which is part of the basic needs of the country's citizens. It is the satisfaction of the need for housing that is the starting point of the country's economic development, as there is a direct relationship between labor productivity and the quality of housing. The able-bodied population-having the opportunity for normal, good rest, communication with family, and a comfortable life-more successfully copes with their responsibilities, and therefore, significantly affects the growth of the country's GDP.

Therefore, when managing the functioning of housing and communal services, it is important to pay special attention to housing and communal services, which are designed to meet the housing needs of people in various forms [10]:

(1) a room, apartment or individual residential building realizes the possibility of individual arrangement of space for a person or an individual family and the creation of household amenities inside residential premises, forms close interpersonal contacts of close people, and provides housing benefits for an individual household;

(2) an apartment building or a group of houses (complex) with an adjacent green areaallows one to make decisions together with neighbors and take specific actions to equip one's home and yard, and to create household amenities in common areas, determine the conditions for the personal communication of people, and provide housing benefits for those living in this house or complex.

We should note especially the state of living quarters today, in the era of the fourth industrial revolution and digital technologies, when robots can monitor the supply of water and electricity, and the analysis of the technical condition of capital construction facilities can be carried out using quadcopters or digital twins. It is during this era in the Russian Federation that the level of emergency and dilapidated housing, i.e., housing not suitable for normal life, continues to grow. According to Rosstat, in Russia, at the end of 2018 there were more than 101,000 buildings (about 25 million square meters) of 
dilapidated housing with more than $70 \%$ depreciation, and with $66-70 \%$ depreciation, i.e., more than 231,000 buildings ( 82 million square meters). Residential buildings recognized as emergency (that is, requiring demolition) at the end of 2018 already covered 12 million square meters. In order to relocate from unsuitable housing, a new house is needed, but the growth rates of budgetary construction projects are extremely small, and do not allow the provision of the required volume of residential premises; commercial housing does not correspond to the solvency of the country's population (Figure 1) $[9,11]$.

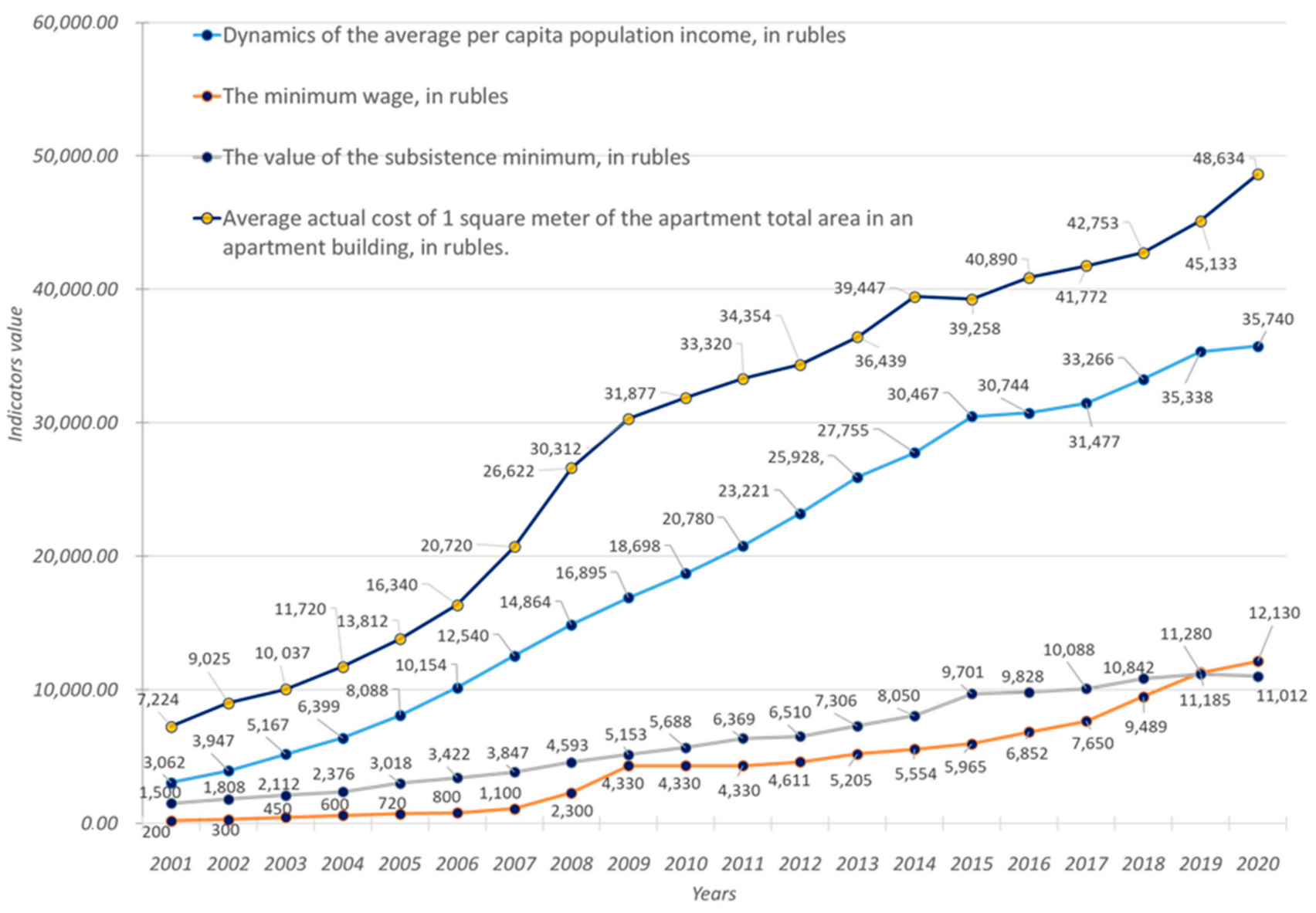

Figure 1. Characteristics of the population's standard of living and the average actual sq $\mathrm{m}$ total area of residential building construction costs (compiled by the authors based on $[9,11]$ ).

On 7 May 2018, the President of the Russian Federation, VV Putin, issued a decree "On the national goals and strategic objectives of the development of the Russian Federation for the period up to 2024" [12-14], which, in particular, spoke about the acceleration of emergency housing resettlement. Large-scale resettlement will be carried out within the project "Housing and Urban Environment" (Figure 2), on which the Russian authorities intend to spend over 1 trillion rubles in six years. The problem concerns almost all regions except Moscow. All other regions, for these purposes, are provided with more than 35 billion rubles annually from the federal budget within the framework of the national project. 


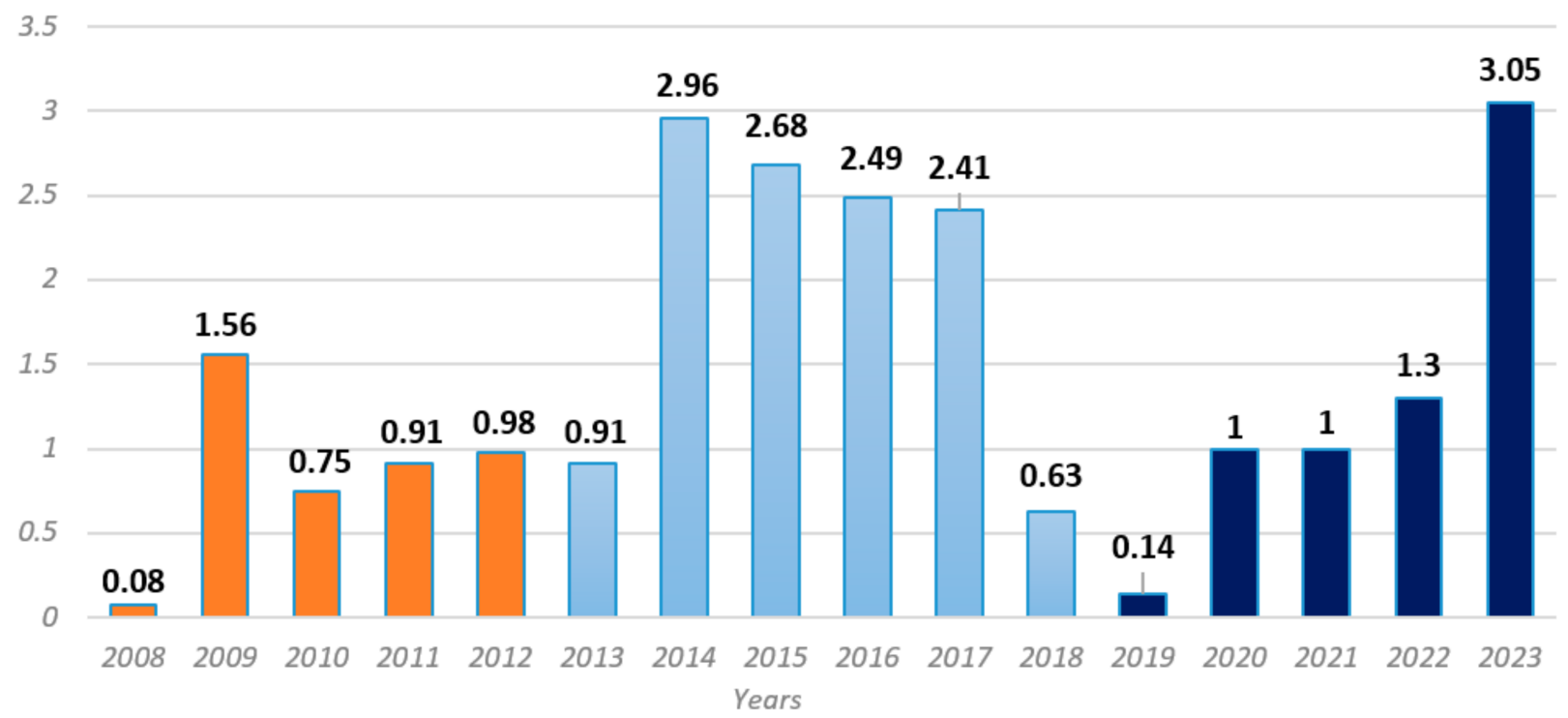

Figure 2. The schedule of emergency housing resettlement in the period from 2008 to 2018, and the planned resettlement from 2019 to 2024 according to the passport of the national project "Housing and Urban Environment" (compiled by the authors based on [9,11,14-16]).

However, as practice shows, not all regions of the Russian Federation succeed in fulfilling the Presidential Decree; in particular, the Pskov region and the Republic of Sokha became "anti-leaders" in the implementation of the federal project "Ensuring a sustainable reduction in the unsuitable for housing stock" under the Housing and Urban Environment Program as of 1 October 2021, according to the Fund for Assistance to Housing and Utilities Reform [14]. This is due to the three reasons discussed below.

Firstly, when analyzing the dilapidated housing stock, the rates of its growth due to the transition of dilapidated houses to the status of emergency ones are not taken into account. This growth averages about 2.3 million square meters per year. However, as 2017, Rosstat [9] stopped publishing data on dilapidated housing, which does not allow us to see an objective picture of the ongoing process, or to quickly assess the situation in the country according to this indicator. As a result, the volume of new residential real estate commissioned annually began to lag behind the rapidly growing volumes of emergency buildings and structures. In general, the balance of emergency and new housing in the country was upset (they should be equal);

Secondly, the efforts of the authorities towards the relocation of dilapidated housing stopped activities in relation to dilapidated housing and communal service facilities. As a result, a new disproportion appeared in the housing sector: a disproportion among the reproduction forms of capital construction objects. This is manifested in the significant predominance of new construction in comparison to other forms of housing renovation. A huge gap between the forms of reproduction of housing in general has been characteristic of the housing construction market in Russia for a long time. As such, in 2000-2019, in the structure of housing reproduction, the reconstruction of the housing stock accounted for no more than $1.3 \%$, and major repairs accounted for no more than $12.9 \%$, while the share of new construction in housing reproduction was no less than $86.7 \%$. In 2019 , in Russia, the share of new construction in the structure of reproduction of the housing stock was $84.7 \%$, major repairs were $15.1 \%$, and reconstruction only made up $0.1 \%$ (Figure 3) [9,17-19]. 


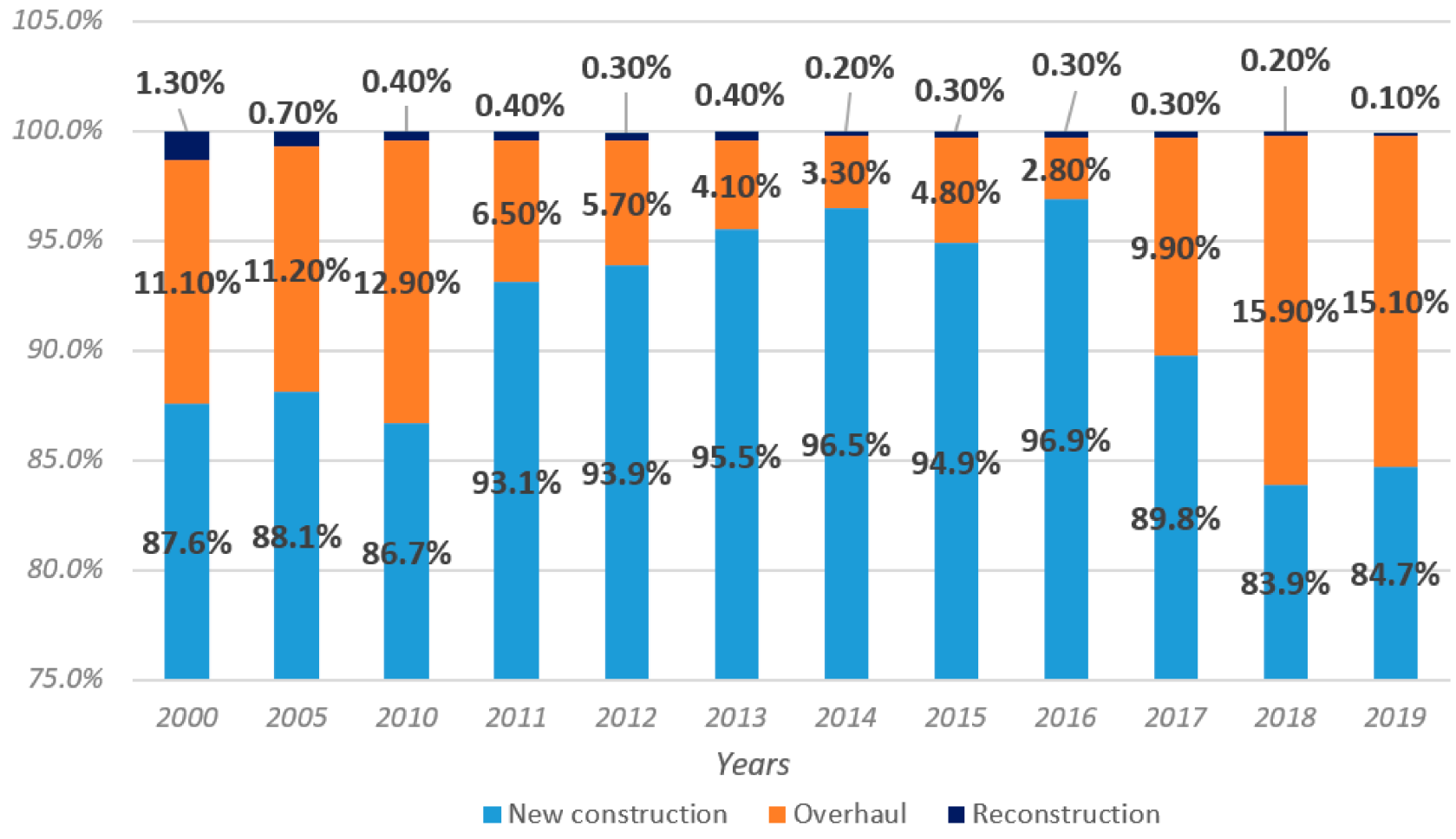

Figure 3. The structure of the housing stock renewal in Russia by reproduction methods (calculated by the authors according to $[9,17-19])$.

Thirdly, it is extremely important to ensure the continuity of the citizen resettlement processes from emergency housing stock and the renovation of dilapidated housing, as well as to continue systematic work on all projects for the modernization of facilities and systems in the housing and communal sector. This is hindered by the lack of constant contact and the coordination of actions between the citizens, government services and intermediary (resource supplying) organizations. Thus, recognizing a house as emergency is a matter of life and death for citizens. However, for municipal authorities, this is just a medium-term decision-making task with a high probability of transferring it to a long-term one, as, on the one hand, the "queue" of those in need of resettlement is only growing every year, and it is difficult to respond to all claims; on the other hand, indicators of the examination of a dilapidated building can be revised if, for example, the house was not recognized as dangerous to the life and health of citizens (Resolution of the Government of the Russian Federation of 28 January 2006 N 47). At the same time, resource-supplying organizations reduce their client portfolio, receive less planned profits, and do not have time to quickly revise their costs and increase the amount of utility bills for the remaining consumers [20].

In order to solve the problems identified above, various tools of the state management of housing and communal service facilities are used today.

The state management instruments of housing and communal services in the Russian Federation can be divided into two groups [21-23]:

1 . The general government management instruments. These are aimed at managing the housing and communal service sphere of the country at the federal and regional levels. These instruments include: the legislation of the Russian Federation, federal and regional target programs of socioeconomic development, tariffs for housing and communal services, and strategies for housing and communal service development, etc. 
2. Local government tools. These are aimed at managing state enterprises, institutions, and organizations in the housing and communal service sphere. The instruments of this group include regulations governing the activities of state authorities, charters of state unitary enterprises and state institutions, and the creation, reorganization and restructuring of state enterprises, institutions, and organizations, as well as their personnel management.

The main government management instruments for the management of the housing sector in Russia is "The Strategy for the Housing sphere Development of the Russian Federation for the Period up to 2025" [14], developed by the Construction Ministry, Housing and Communal Services of the Russian Federation.

In turn, "the Strategy for the Housing sphere Development of the Russian Federation" has its own implementation instruments. The main instruments for the implementation of the strategy are listed below:

(1) mortgage lending is the main instrument for acquiring home ownership;

(2) commercial rental housing is an instrument for both the short-term and long-term solution of the housing issue;

(3) non-commercial rental housing is an instrument to support socially priority categories of citizens;

(4) mortgage-backed securities are an investment instrument that provides an investment yield higher than federal loan bonds;

(5) instruments for the changing of the urban environment are instruments that have a direct impact on the achievement of the goals of forming a balanced ratio of supply and demand in the Russian housing market;

(6) standards for the integrated development of territories are an instrument for the transformation of cities;

(7) the "State information system of housing and communal services" (GIS housing and communal services) is an important instrument of government management in the field of housing and communal services. This system was created back in 2014 by the Federal Law of 21 July 2014 No. 209-FL “On the state information system of housing and communal services", and worked in test mode until 2017 [24]. GIS Housing and Communal Services is an information portal where one can create electronic voting on any issues related to the management of apartment buildings.

These instruments should help in solving the main task of the Russian Federation housing policy: providing the population with affordable housing in a comfortable urban environment [14].

However, there is a global difference in the composition of this toolkit in the Russian Federation and in foreign countries. This difference is mainly due to the rights of homeowners. In international practice, the priority in making decisions regarding the management of a residential building belongs to the owners [25-30]. These overseas homeowners unite in a non-profit consumer organization. This organization unites owners of real estate objects or shareholders. This organization's purpose is to manage the complex of the real estate, and to ensure the operation of this comple and the possession, use and disposal of property. The homeowner's association has become a generalizing concept of housing cooperation in various legal forms, such as Planning Unit Developments, Condominium Associations, and Housing Cooperatives in the United States and Canada; syndicates in France; and apartment joint stock companies in Finland [22,31-33]. 
In European countries, residents themselves monitor the house condition and receive financial support from the authorities. For example, in Germany, France and Holland, people have the right, in agreement with the municipality, to build (including with the involvement of investors) an object of shared ownership on their land plot, and to save money for overhaul during the operation $[28,29,34]$. Furthermore, in some countries, there are a state grants system and subsidies for major repairs of houses: they provide the authorities with a project of work, and, if it meets the approved criteria, they receive state aid [29,35-38].

The best world experience in the management of housing and communal services and housing construction belongs to Germany. Here, the townspeople themselves can act as customers for the construction of a residential building [28].

The French system of housing and communal service management is designed in such a way that about $60 \%$ of the townspeople can obtain social rental housing in multi-story buildings owned by the municipality. That is, residents are not at all burdened with worries about their own apartments. Instead, they gain confidence in the future and mobility: they choose a place of residence based on their professional interests. At the same time, social rental housing there is of higher quality than commercial housing. Municipalities are responsible for its renovation, and it is not profitable for them to save money during the construction phase, as this will lead to high costs in the future [39,40].

However, the most effective tools for changing the urban environment today are digital technologies in the foreign practice of housing and communal service management.

At present, intelligent systems are rapidly developing, and everywhere take the place of traditional information processing and control systems. The most significant successes have been achieved in the development of expert systems, intelligent systems for diagnostics, forecasting, planning, management, decision support, design, information retrieval, and the processing of natural-language information. Such systems are created using intelligent technologies, including software and hardware for the implementation of intelligent methods and algorithms [41,42].

A special place was given to the development of intelligent learning systems based on logic and neural networks, as well as cognitive systems that use the principles of the organizing structure, functions and behavior inherent in the human nervous system, possessing the ability, in particular, to accumulate knowledge in the process of functioning, and even to solve some creative problems. On this path, intelligent technologies become biological, which can significantly accelerate the development of intelligent systems.

Artificial intelligence can simplify and accelerate the process of the interaction between all of the participants in the management of housing and communal service facilities. It is the most popular disruptive technology in the digital marketplace around the world in the 21 st century. It makes any activity more productive and smarter by integrating machine learning algorithms into various products and services. The global AI market is expected to reach $\$ 93.53$ billion in $2021[43,44]$.

Capgemini Research Institute, Intelligent Automation in Energy and Utilities, conducted the study "The next digital wave" in 2019. This study was devoted to the assessment of the implementation of artificial intelligence in housing and communal services. The study involved 520 companies from 16 countries. The AI technologies included in this study were speech recognition, natural language generation, context-aware computing, biometrics, image and video analysis, machine and deep learning, swarm intelligence, and chatbots or voice bots [26].

The study results showed that the dynamic growth in the number of companies developing AI solutions for housing and communal services began in 2015. The leaders in the development of AI in housing and communal services are North America and the $\mathrm{EU}$, but the countries of the Asia-Pacific region, given their growth rates, may become new leaders by 2025. The implementation of AI in the housing and utilities sector of large cities around the world is usually not an industry priority for urban AI development 
initiatives [26]. Implementation takes place pointwise, depending on the problems of the city's development. Most AI projects are in the pilot phase.

The study noted that the most attractive areas for investment are groups of solutions focused on B2C or B2B2C segments (smart home systems, platforms, and applications for providing services to residents). Investors' interest in systems for the monitoring of the state of engineering infrastructure is also high [26].

The analysis of international experience shows that the basis of successful cases for the introduction of digital technologies is the creation of a basic infrastructure (sensors for the collection of data, platforms for their processing), as well as a high involvement of the authorities and residents of the city [45-48]. Leaders develop the sector by stimulating data sharing. However, Russia, in terms of most indicators, except for the high development of communication networks and $4 \mathrm{G} / 5 \mathrm{G}$ penetration, is inferior to other countries in the world in terms of infrastructure development for the implementation of $\mathrm{AI}$ in housing and communal services [49]. As a result, the introduction of digital technologies is not yet a priority for the housing and communal services sphere of the Russian Federation, and is not included in the "Strategy for the development of housing and communal services until 2030" [26].

However, the solution to the above problems of housing and communal services is mostly associated with the use of digital technologies [49]. The inclusion of the procedure for the introduction of digital technologies into the basic tools of public administration could seriously change the general condition of housing and communal service facilities. The combination of artificial intelligence machines and human workers can increase productivity and reap huge benefits in this field.

As evidence of this trend, consider two options for the renovation of the housing stock in Russia: (1) using digital technologies, and (2) without using modern digital technologies (see Figure 4). It can be seen from the schedule that the use of artificial intelligence and digital technologies will increase the annual commissioning of housing in 5 years by $50 \%$.

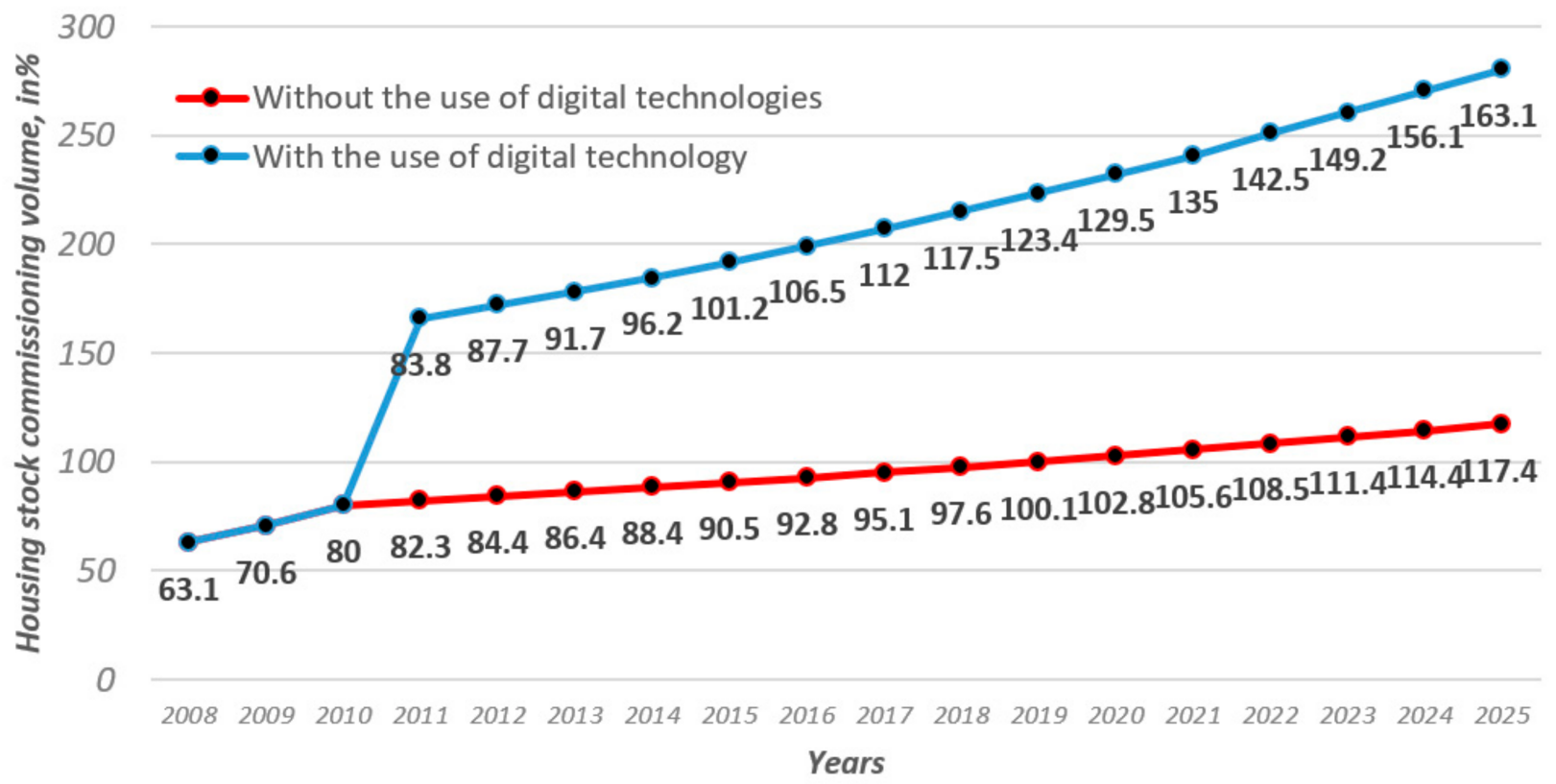

Figure 4. Dynamics and forecast of the housing stock commissioning volume in relation to 2008 with and without the use of digital technologies, as a percentage (calculated by the authors according to $[9,50-53])$. 
This forecast (Figure 4) was compiled on the basis of the implementation results of digital technologies in several Russian regions and cities (Sakhalin Oblast, Udmurt Republic, Belgorod Oblast, Moscow, Nizhny Novgorod) [25]. In these Russian Federation constituent entities, digital technologies were next applied for the implementation of construction projects, e.g., the processing of digital technology of tender applications based on artificial intelligence, the technology for obtaining a digital construction order based on the use of online neural network video analytics to identify defects, etc. This has led to serious positive changes. Most of the processes have accelerated 5-10 times (preparation of documents, logistics of resources, training, etc.), and the cost of some types of work has decreased by $20-30 \%$ [26].

Summing up the issue of the relevance of the formation of management initiatives by creating conditions for the sustainable development of housing and communal service facilities based on the interconnection of the activities of all of the participants in this process and the use of modern digital technologies, it is important to note that work in this direction should take into account all of the existing industry problems and all of the stop factors and opportunities for their development [26]. Therefore, the scientific hypothesis of this study lies in the assumption that, for the sustainable development of urban objects facilities, it is possible to:

- formulate criteria for the assessment of the sustainable development of urban agglomerations;

- develop instruments for the management and assessment of the housing and communal services state, which at all of the stages of the sustainable development strategy will make it possible to form an up-to-date database of capital construction objects suitable for living.

Research objectives:

1. Analyze the current state of the housing and communal services industry in the Russian Federation in terms of the sustainable development concept of territories.

2. Assess the needs of the housing and communal service industry in the use of digital technologies.

3. Clarify the use of digital technologies in the management of the capital construction of housing and communal services.

4. Clarify the methods for the assessment of the development of cities and urban agglomerations.

5. Determine the criteria list that characterizes the sustainable development of housing and communal services.

6. Form organizational and analytical model for the assessment of the quality of the sustainable development of housing and communal service capital construction objects.

7. Determine the sustainable development goals (results) of urban agglomerations in the Russian Federation.

8. Form databases of housing and communal service objects suitable for habitation, considering the form of their reproduction (new objects, operated objects, dilapidated objects).

9. Develop a strategic roadmap for the sustainable development of object housing and communal services for the period 2021-2035, indicating the periods of implementation of digital technologies used in the management of housing and communal services capital construction objects.

In order to conduct the study, the following methods were used: the system analysis method, infographic modeling, aggregation, the process optimization method, synthesis, retrospective analysis, and forecasting. 


\section{Materials and Methods}

An analysis of the housing and communal service industry showed that the main problem facing the state sector is the rapid growth of dilapidated housing. The government management tools used do not enable the control of this process. International practice shows that it is necessary to solve such a problem in a comprehensive manner. First, we need to progress and clarify general management tools for the housing and communal services sector of the country at the federal and regional levels [26]. Secondly, we need to modify old and create new local tools aimed at managing state enterprises, institutions, and organizations in the housing sector [54-56].

In order to solve the described problem, the authors of the study consolidated the following methods and end-to-end digital technologies based on artificial intelligence: (1) general methods of infrastructure facilities system analysis in some large cities and urban agglomerations; (2) infographic modeling; (3) intelligent decision support systems (decision intelligence); (4) methods of optimizing work within the urban ecosystem (automatic systems); (5) production optimization methods using artificial intelligence by automating data, model and application updates (artificial intelligence engineering/AI engineering).

\subsection{General System Analysis Methods of Some Large Cities and Urban Agglomeration Infrastructure Facilities}

All of the existing methods for the assessment of the development of cities and urban agglomerations can be divided into two types, depending on the purpose and scope of the study: "universal", aimed at assessing the development of large cities and agglomerations masses within a country or macroregion (hereinafter referred to as methods of the first type), and "individual", allowing the assessment of the development of one or more specific cities or agglomerations (hereinafter referred to as methods of the second type) [57,58].

The methods of the first type are more numerous. Their advantage is their relative simplicity of use. However, the flip side of these advantages is ignoring the internal structure of agglomerations (except, in some cases, the delimitation of the core and the periphery) and the variety of processes occurring in them. Such techniques are based on several basic indicators related to the agglomeration as a whole, which is thus interpreted, if not as a point, then, at best, as an aggregate of the nucleus and a peripheral zone that is homogeneous in terms of its characteristics. In addition, the universality requirements force the use of publicly available official statistics in the calculations, the set of which is limited, and the degree of reliability (especially in Russia) is often low. This imposes additional restrictions on the applicability of first-type techniques.

In Russian practice, the best known methods of this type were developed in the 1970-80s by the Central Scientific Research Institute of Urban Planning and the Institute of Geography of the Academy of Sciences of the USSR. They are similar in the approaches and methods used, but differ in their details [59].

The development of the agglomeration is assessed in these methods by calculating a special coefficient. In the methodology of the Institute of Geography, the coefficient of development considers the values of the population of cities and urban-type settlements in the agglomeration, and their share in the population of the agglomeration.

In the methodology of the Central Scientific Research Institute of Urban Planning, a similar coefficient is calculated as the ratio of the urban settlement number in an agglomeration to the product of the agglomeration territory area and the shortest distance between urban settlements in the agglomeration. In addition, in this technique, along with the development coefficient, the so-called agglomeration index is used, i.e., the ratio of the peripheral zone urban population to the entire agglomeration urban population.

Thus, both described approaches to the assessment of the development are based on the indicators of the settlement system, i.e., the population size, number, and population density of settlements, and -in the case of the Central Scientific Research Institute of Urban Planning methodology-density characteristics. According to these methods, the only indicator of internal connectivity within an agglomeration is transport accessibility. 
In the post-Soviet period, individual researchers turned to the task of developing a universal integrated system of indicators for the assessment of the development level of agglomerations, but agglomerations were still most often regarded as territories that were homogeneous in their characteristics. Foreign experience in the assessment of the level of agglomerations development is richer, and often approaches the assessment of the agglomeration effect in the economy. However, the methods used by foreign researchers also, for the most part, involve the calculation of indicators and indices for agglomerations without taking into account the properties of their individual parts.

For example, Uchida and Nelson used three criteria in their proposed Agglomeration index of territories: the population density of the territory (urban area), the population of the core city (large city center), and the temporary accessibility to the core city [60-62].

Another example is the Sustainable Development Index calculated for US metropolitan areas. It includes 16 sustainable development parameters and sub-parameters, initially presented either as a percentage or in per-capita units. Each parameter is normalized so that it can be represented in the range from 0 to 100 using Formula (1) [63]:

$$
x^{\prime}=\frac{x-\min (x)}{\max (x)-\min (x)} \times 100,
$$

where $x^{\prime}$ is the final normalized parameter value, $x$ is the actual parameter value, and $\min (x) \operatorname{umax}(x)$ are the maximum parameter values for the entire sample.

Thus, the agglomeration with the best value of this parameter recieves 100 points, and the worst one receives 0 . In some cases, the indicators are additionally standardized for the upper and lower boundaries; for example, if target values are set for an indicator at the national level, then all of the agglomerations with higher values of these parameters receive 100 points, and the rest are normalized relative to the target value. The final index is determined based on the arithmetic mean for all of the parameters for each metropolitan area. However, the method does not consider the variation of the parameter values across the agglomeration territory.

The methodology for the assessment of the development of agglomerations in Germany works in a similar way. The assessment is based on 26 particular indicators, which are aggregated into 5 complex indices. Within each indicator, a ranking is built among all of the agglomerations; then, the ranking is performed again for each index, taking into account the rating by indicators within this index. The final "rating" (from 1 to 12) is graphically displayed on the corresponding axis of the pentagonal chart [64].

In the same relatively few cases, when researchers in one way or another assess the relationship between the municipalities of the agglomeration, the object of assessment is, as a rule, not the development of the agglomeration as a complex characteristic, but particular aspects of the agglomeration's functioning.

As an example, the Sprawl Index [41,65-67] is calculated for metropolitan areas of the United States in order to assess the degree of their extensive growth ("sprawl"). This index, however, considers such parameters as the connectivity of the street network, building density, and a variety of land uses. In this regard, we can also note the experience of the calculation of the Conurbation Index, evaluating (using the example of the Porto Alegre agglomeration in Brazil) the transport connectivity of the agglomeration parts among themselves and comparing it with the overall connectivity within the agglomeration [68].

In a few methods, in addition, indicators for the agglomeration as a whole and for the central city are calculated separately, which makes it possible to indirectly assess the role of the center in the agglomeration. An example is the city prosperity index, calculated for large cities and metropolitan regions (agglomerations) of the world according to the UN-Habitat methodology, based on weighted and scored values of private statistical indicators [69].

Techniques of the second type ("individual") are opposite to the techniques of the first type in terms of advantages and disadvantages. The enlarged scale of the study makes it possible to study in detail the structure of the agglomeration in all of the variety of ongoing processes and not be limited to official statistics, using non-standard and sometimes costly 
methods of collecting information (sociological surveys, visual observations, analysis of "big data", etc.). But this is precisely why such techniques are clearly applied in nature and work only for specific agglomerations, being limitedly applicable to others. As a rule, the methods of the second type use "thin" tools, and allow us to identify the real boundaries of the agglomeration with high accuracy, regardless of the network of administrative (municipal) units [59].

Research carried out by the methods of the second type has become widespread in Russia only in recent decades. This is due to the emerging demand from both society and the state to develop mechanisms for the management of the development of agglomerations. Such mechanisms cannot be developed without obtaining a detailed understanding of the boundaries, structure and nature of the agglomeration development. The most famous are the studies of the Irkutsk and Chelyabinsk agglomerations, carried out with the involvement of a wide range of experts from all of the over the country.

The results of the latter formed the basis of the monograph [70], which, along with a detailed analysis of the Chelyabinsk agglomeration, contains a systematic review of the theory and practice of managing the development of agglomerations abroad and in Russia. It is important to note that within the study, the authors did not stop at specifying the boundaries of the Chelyabinsk agglomeration, but approached the problem of the assessment of its development, precisely from the standpoint of its internal structure. Thus, the specialization of territories within the agglomeration was determined, and the so-called "integral development potential" was calculated (the integral development potential is formed, according to the presented methodology, by the "index of the achieved level of economic growth" (calculated on the basis of official statistics) and "development resource index" (determined on the basis of expertly evaluated indicators characterizing the administrative status, transport potential and the state of the economic and legal environment of the municipality) for each of the municipalities included in the agglomeration.

\subsection{Infographic Modeling}

Infographic modeling is an approach to construction design that allows one to visually perceive the image of a capital construction object. It can consider infographics as a visual interpretation of all of the kinds of data on the objects in question. Moreover, the quantitative or qualitative nature of the criteria describing capital construction objects does not matter [71-73].

In order to describe the complex interaction of all of the subjects of the housing and communal services system, infographics are the most effective tool, as they take into account different approaches to the formation of descriptive criteria for each subject of the housing and communal services system, and have no boundaries in relation to their dimensions.

\subsection{Intelligent Decision Support Systems (Decision Intelligence, Autonomic System)}

Intelligent Decision Support Systems (IDSS) are decision support systems that use artificial intelligence (AI) extensively. AI is a technique that allows machines to simulate human behavior. Artificial intelligence is the theory and design of computer systems capable of performing tasks normally requiring human intelligence, such as visual perception, speech recognition, decision making, and translation between languages. Decision intelligence (DI), or an intelligent decision-making system, is a modern approach in which the decision-making process is carried out with the help of additional analytics and artificial intelligence [46,74-78]. This approach enables leaders to make faster, more accurate, and consistent decisions based on analytics of complex data and the aggregation of all of the disparate stores within the organization. The goal of DI is also to maintain "explainability" with a clear emphasis on easy understanding and accessible meaning for each process of the organization in question. The decision analytics that this technology implements are largely action-oriented, and go beyond data analysis, as this allows one to make suggestions and recommendations on what to do for the manager in the future [79,80]. In fact, DI makes decisions on a par with the head, and, therefore, has a clear advantage in the management 
of the city's housing and communal services, as the latter presupposes the interconnection of large-scale databases of subjects and objects of the urban economy, and their constantly changing and newly emerging characteristics [46,81,82].

The second type of intelligent decision support systems that is actively used today in the work of a manager is the Autonomic System (AS) or autonomous systems. They are physical or software systems that are automatically trained on data from the environment and modify their own algorithms to optimize their performance within the ecosystem [83-87].

For the purposes of this study, the most interesting ecosystem is artificial intelligence, which is an attempt by humans to exploit the electronic, digital, or mechanical advantages of artificial intelligence technology to reduce the speed at which persistent and repetitive actions are performed.

\subsection{Optimizing Production with Artificial Intelligence by Automating Data, Model and Application Updates (Artificial Intelligence Engineering/AI Engineering)}

Artificial intelligence engineering is one of the new directions in the development of AI, focusing exclusively on the creation and development of intelligent tools, machines and systems to improve the living standards of society. AI Engineering covers a wide range of computing powers and massive datasets with the integration of machine learning algorithms. This approach helps businesses to create smart decision-making processes to meet customer needs and increase customer engagement. Engineering expertise is essential to effectively create, manage, and analyze AI functions [88-90].

Combined with data analytics, AI and machine learning facilitate predictive analytics: a technique that can provide predictions for strategic goals like business planning, or for practical applications like predictive maintenance. These technologies, embedded in software, can lead to the creation of expert systems that assist practitioners in fields such as medicine, exploration, and military applications [91-95].

What is artificial intelligence engineering? Essentially, artificial intelligence engineering is the use of algorithms, computer programming, neural networks, and other technologies in the development of artificial intelligence applications and methods. These methods and applications usually find practical application in commerce, science, and other areas of life [96-100].

Therefore, an artificial intelligence engineer must be able to efficiently extract data from various sources, design algorithms, build and test machine learning models, and then deploy those models to create AI applications that can perform complex tasks.

AI engineers can quickly add machine learning capabilities to mission-critical systems such as enterprise resource planning (ERP), customer relationship management (CRM), and mobile device management (MDM). They can also develop ad-hoc applications using artificial intelligence with the required level of security from scratch [47,92].

Artificial Intelligence Engineering enables organizations to build hybrid operating environments that combine data science, data engineering, and software development.

Depending on the industry, AI engineers also work with other AI and IT professionals to facilitate data management and process automation across the enterprise [101,102]. For example, in manufacturing, AI developers work closely with electrical engineers to develop software that builds artificially intelligent robots. In retail and other sectors, AI engineers develop machine learning models and collaborate with data scientists to manage large and complex datasets that enable predictive analytics [103,104]. At the strategic level, business intelligence (BI) developers design, model, and analyze complex data to identify industry patterns and market trends [54,105-108].

The consolidation of all of the above methods and approaches to the management and assessment of individual elements of the urban economy or urban agglomeration allowed the authors of this study to form the author's organizational and analytical model for the identification and assessment of the quality of the sustainable development of capital construction reproduction forms of housing and communal services (Figure 5) (capital 
construction objects are understood as buildings, structures, objects of construction in progress, and linear objects). Capital construction objects have the following main features: a strong connection with the ground, a buried foundation, and the inability to move them without causing disproportionate damage to their purpose [109]. It is important to note that this model is both quantitative and qualitative. It involves a multidimensional study of all of the capital construction objects' reproduction forms in housing and communal services, considering their condition at the time of the strategy formation's beginning, i.e., ex post analysis of housing and communal service objects for 2021. By analogy with macroeconomic analysis, ex post is an analysis of statistical data on the object under study or a set of objects. This analysis allows us to assess the current state of the object under study, identify problems and negative phenomena in its functioning, develop a policy to solve and overcome them, conduct a comparative analysis of similar housing and communal service objects located in other cities, and predict their state in the future (foresight analysis until 2035). Within the framework of this study, foresight analysis (foresight forecast) is a system of methods for the expert assessment of the strategic directions of the socioeconomic and innovative development of cities, identifying technological breakthroughs that can affect their economy and citizens in the medium and long term [40]), and their desired state in the future. The ex ante analysis of housing and communal services until 2024 and until 2027, by analogy with ex ante macroeconomic analysis, allows for the future-state predictive modeling of the object under study or a set of objects based on certain theoretical concepts and applied experience. This allows one to determine the patterns of development of housing and communal services, and to identify the cause-and-effect relationships between their changes and the sustainable development of cities. In addition, this approach makes it possible to introduce modern digital technologies based on AI into the implementation of the proposed strategy, and to form progressively a sustainable urban ecosystem.

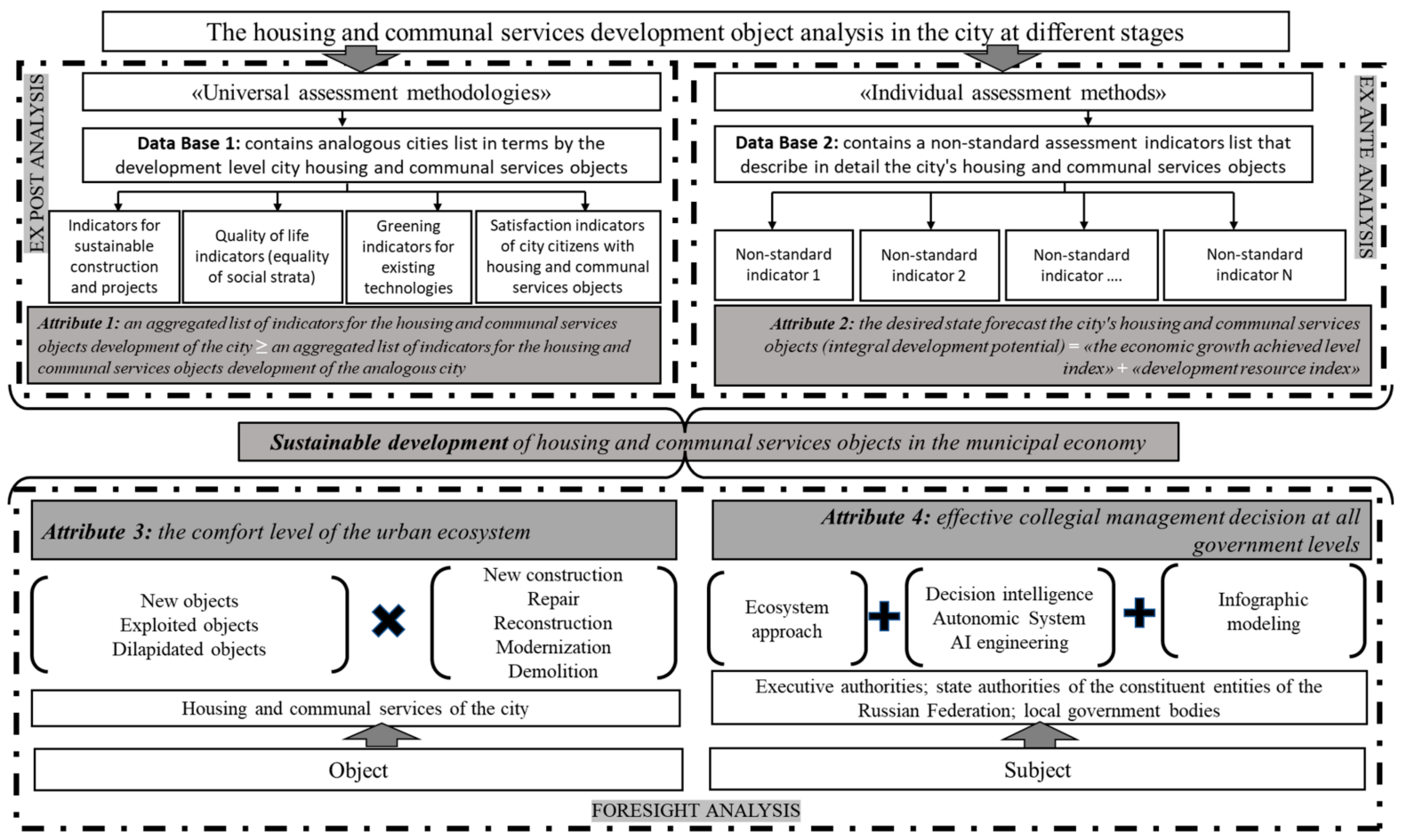

Figure 5. Organizational and analytical model of the identification and quality assessment of the sustainable housing and communal service object development of the municipal economy (compiled by the authors).

According to Figure 5, under the sustainability of housing and communal service object development of the municipal economy, the authors of the study understand such a 
state of the objects under consideration, which is characterized by the following integral list of properties that exist simultaneously:

(1) an aggregated list of indicators for the housing and communal service object development of the city $\geq$ an aggregated list of indicators for the housing and communal service object development of the analogous city;

(2) the desired state forecast of the city's housing and communal service objects (integral development potential) $=$ «the economic growth achieved level index» (calculated based on official statistics) + «development resource index» (determined on the basis of expertly evaluated indicators characterizing the administrative status, transport potential and state of the economic and legal environment of the municipality));

(3) the comfort level of the urban ecosystem, which depends on the constant monitoring of the types of objects of housing and communal services in the aspect of the prospects for their transformation into one of the capital construction objects' reproduction forms;

(4) the effective collegial management decision of the executive authorities, the state authorities of the constituent entities of the Russian Federation, and local government bodies, formed using the ecosystem approach. This is a strategy for the integrated management of land, water and living resources that promotes their conservation and sustainable use in an equitable manner. It is based on the application of appropriate scientific methodologies focused on levels of biological organization that encompass the basic processes, functions and interactions between organisms and their environment, and end-to-end AI technologies for projected infographic models of municipal housing and communal service management.

\section{Results}

In order to apply the organizational and analytical model described above when developing a strategy for the sustainable development of housing and communal service object development (see Figure 5), the authors proceed from the assumption that the sustainability of the city depends both on the material and physical objects of housing and communal services, and on the social and environmental components of such a complex and dynamic structure as a modern city, as the sustainable development of each individual city should go along with the provision of both the national direction towards sustainability, and the global trend, which was set in 2015 by the UN General Assembly Resolution No. A70/L.1 "Transforming our world: the 2030 Agenda for Sustainable Development" [1].

In order to form a strategic roadmap for the sustainable development of housing and communal services in the municipal economy strategy of the Russian Federation (hereinafter referred to as the "roadmap"), the authors of the study selected two world goals from the UN General Assembly Resolution: No. A70/L.1 [2]-No. 11 and No. 9 (see Table 1). The selected goals are directly related to the problems of urban infrastructure's sustainable development, as they are aimed at achieving conditions for sustainable development through the joint efforts of governments, the private sector, civil society, and the inhabitants of the Earth. In Table 1, below, the goals selected by the authors correlate with the goals of the sustainable development of the Russian Federation at the federal, regional, and municipal levels $[2,12,13,110-112]$, and the planned macroeconomic results of the road map. 
Table 1. Compliance with the sustainable development goals for the federal, regional, and municipal levels and the planned macroeconomic results (compiled by the authors).

\begin{tabular}{|c|c|c|c|}
\hline $\begin{array}{l}\text { World-Class } \\
\text { Goal Formulation }\end{array}$ & $\begin{array}{c}\text { Formulation of Sustainable } \\
\text { Development Goals at the } \\
\text { Sectoral Level (Housing } \\
\text { and Communal } \\
\text { Services Industry) }\end{array}$ & $\begin{array}{l}\text { Formulation of Goals for } \\
\text { Sustainable Development at } \\
\text { the Municipal Level (at the } \\
\text { Level of Housing } \\
\text { and Communal } \\
\text { Services Facilities) }\end{array}$ & $\begin{array}{l}\text { Planned Macroeconomic Results } \\
\text { of the Roadmap Implementation }\end{array}$ \\
\hline
\end{tabular}

Ensuring coordination of the activities of federal executive authorities, state authorities of the constituent entities of the

Russian Federation, local governments, and development institutions for organizational and regulatory support for accelerating the development of housing and communal services in the Russian Federation [13].

Goal 11

Make cities and towns inclusive, safe, sustainable [2]
Goal 9. Build resilient infrastructure, foster inclusive and sustainable industrialization and innovation [2]
Formation of a set of organizational, regulatory, and institutional measures that ensure the development of housing and communal services in the Russian

Federation, coordinated in thematic areas and terms of implementation $[13,20]$.

Optimization of approaches to the development of housing and communal services due to the synergistic effect from the allocation of government regulation measures differentiated blocks [13,20].

Development of a concept for the development of housing and communal services in Russia as an integral part of the Strategy for the spatial development of cities and urban agglomerations of the Russian Federation and the Strategy for the development of the construction industry and housing and communal services of the Russian Federation until $2035[2,13]$.

A virtual organizational and economic model for managing housing and communal services objects for the entire period of their life cycle is creating, based on the United

Nations sustainable development principles.

Creation of conditions for real residents' participation in the processes of housing and communal services management $[2,13]$.

Implementation of end-to-end

process of assessing and and communal services objects.

\section{Adaptive AI models for} housing and communal services, capable of continuously evaluating digital models of housing and communal services objects are creating.

A housing and communal services objects digital models are creating.
Full results:

\section{improving the places of} Russian cities in the Mercer rating [84] in terms of the urban environment quality (quality of the population life): in 2019, Moscow was in 167th place, and in 2020, due to COVID-19, Mercer decided not to publish the rating; the entry of 2-3 Russian cities into the number of world (global) cities in terms of parameters/indicators of the annual survey by Price Waterhouse Coopers "Cities of Opportunities" [113]; the digitalization index "IQ of cities" (The index "IQ of cities" was developed by the Ministry of Construction of Russia in 2019 together with the Lomonosov Moscow State University within the framework of the departmental project "Smart City" (national projects "Housing and Urban Environment" and "Digital Economy") by 2035 (203 cities) $80 \%$ for $70 \%$ of cities [53]; improving Russia's position in the DoingBusiness ranking: from 28th place in 2020 to move to the top ten countries by 2035 [50].

It should be noted that the selected targets for the formation of the "road map" were considered by the authors of the study only in terms of the development of housing and communal services in the medium and long term. In order to do this, all of the objects of 
housing and communal services of the municipal economy needed to be divided into three groups according to the criterion of their suitability for living:

(1) new capital construction objects (NCCO). These are new residential buildings, as well as new buildings and structures designed to perform various types of production processes, the storage of products, the temporary stay of people, and the movement of people and goods [109]. The database on new capital construction objects (Base NCCO) contains criteria for their investment attractiveness for all of the groups of stakeholders- $I N_{i}$, where $i \in[1 ; N]$, and $N$ is the number of criteria for the investment attractiveness of housing and communal service facilities of the primary market/primary operation (for utility networks).

(2) exploited capital construction objects (ECCO). These are residential buildings, as well as buildings and structures designed to carry out various types of production processes, the storage of products, the temporary stay of people, and the movement of people and goods. For these construction objects, the effective operation minimum duration of load-bearing structural elements has expired. This duration is determined in Appendices 2 and 3 to the Order of the State Committee for Architecture of the State Construction Committee of the USSR of 11/23/1988 N 312 [114]. The database on exploited capital construction objects (Base ECCO) contains the criteria for their investment attractiveness for all of the groups of stakeholders- $I E_{k}$, where $k \in[1 ; M]$, and $M$ is the number of criteria for the investment attractiveness of housing and communal service facilities of the secondary market/permanent operation (for utility networks).

(3) dilapidated capital construction objects (DCCO). These are new residential buildings, as well as new buildings and structures designed to perform various types of production processes, the storage of products, the temporary stay of people, and the movement of people and goods. The state of the structures of these objects, as a result of high physical wear and tear, ceases to meet the specified operational requirements [114]. The database on dilapidated capital construction objects (Base DCCO) contains criteria for their accident rate for all of the groups of stakeholders- $I D_{g}$, where $g \in[1 ; G]$, and $G$ is the number of criteria for the accident rate of housing and communal service facilities of dilapidated housing stock/dilapidated utility networks.

Furthermore, the construction of the "road map" was associated with the process of the selected groups of housing and communal service objects reproduction. Each group of housing and communal service objects were assigned their own forms of reproduction (new construction, major repairs, current repairs, reconstruction, modernization, demolition in accordance with the criteria that characterize them (Figure 6 stage 1 and 2). This made it possible to obtain high-quality databases for all of the groups of objects of housing and communal services of the Russian Federation: Base NCCO $=\left\{\mathrm{IN}_{i}\right\}$-new housing and communal service facilities; Base ECCO $=\left\{\mathrm{IE}_{k}\right\}$-exploited objects of housing and communal services; and Base $\mathrm{DCCO}=\left\{\mathrm{ID}_{g}\right\}$-dilapidated objects of housing and communal services (Figure 6 stage 3 ). 


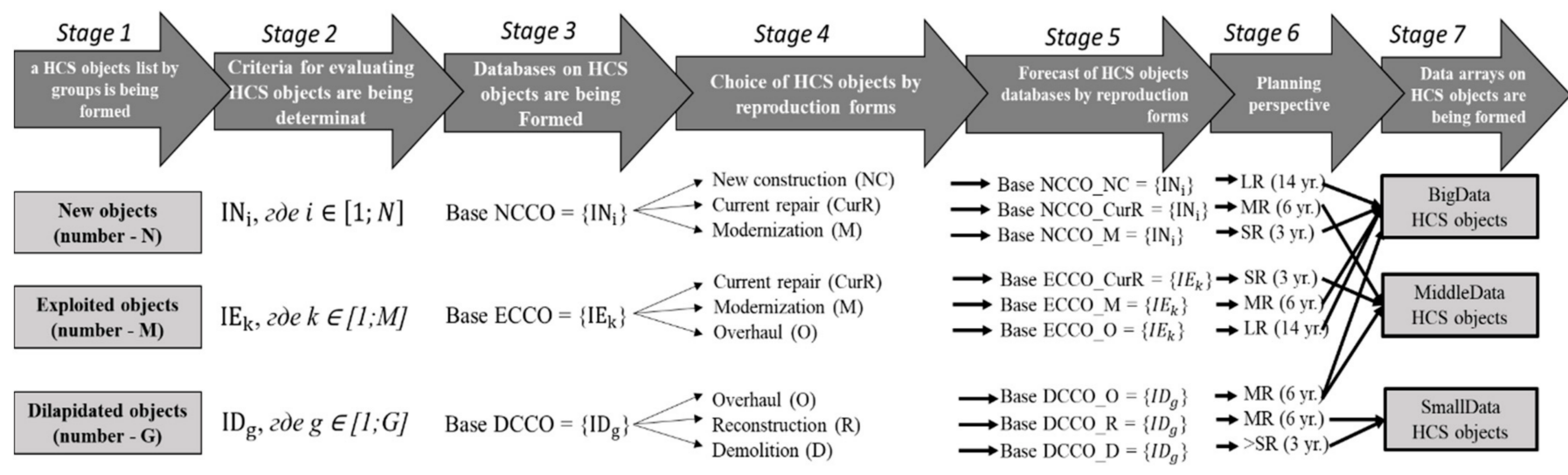

Figure 6. Detailing the formation of a database process to create a strategy for the sustainable development of housing and communal service objects (HCS) (compiled by the authors).

The obtained databases were used to distribute housing and communal service objects according to future possible forms of reproduction (see Figure 6 stage 4). As a result, the databases of housing and communal service facilities were predicted considering their forms of reproduction (see Figure 6 stage 5). Furthermore, the forecast databases were distributed over the planning periods necessary for the formation of the "road map" (Figure 6, stage 6). All of the planning perspectives are associated with individual stages of the roadmap proposed by the authors (see Figure 7).

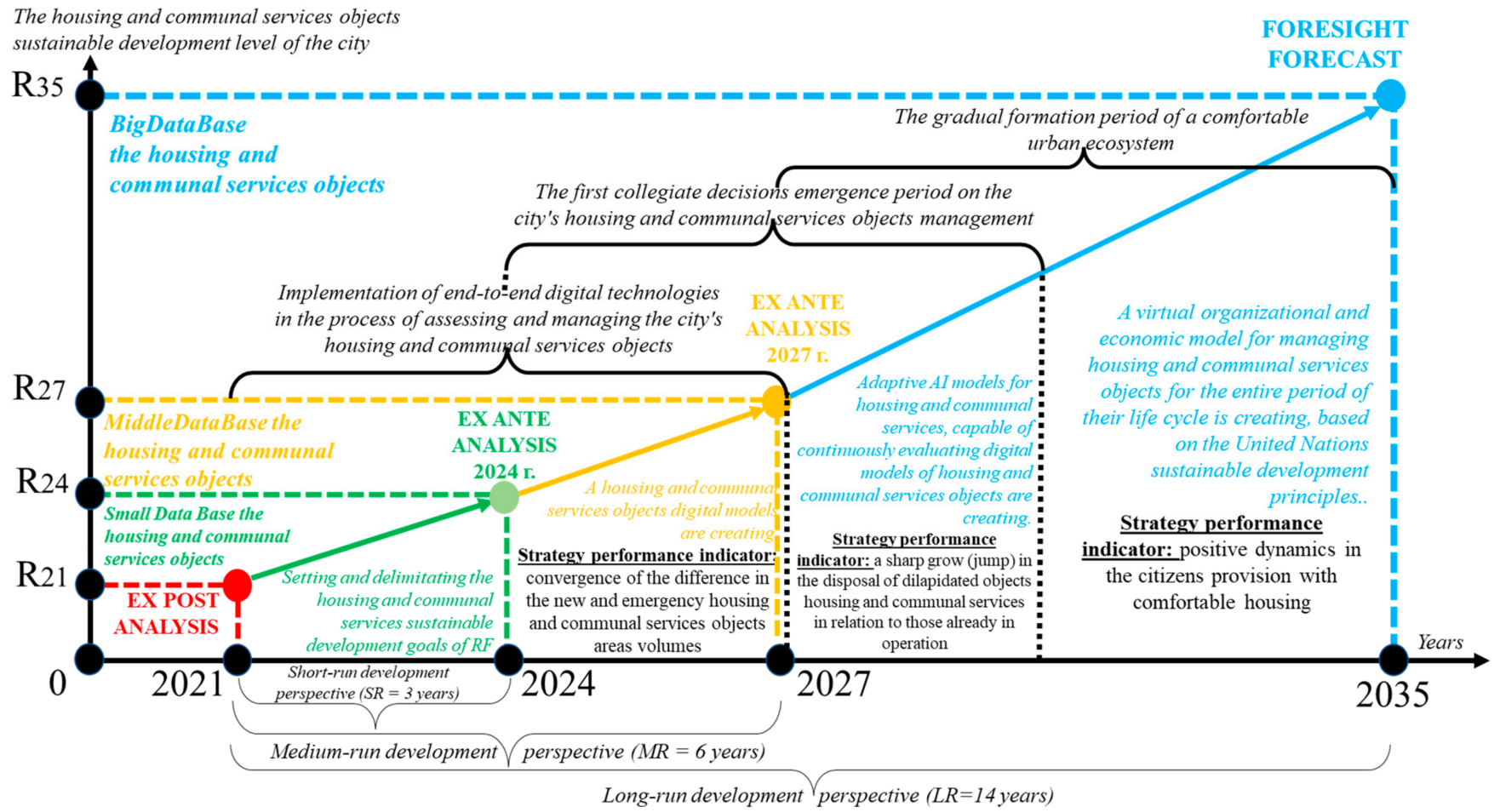

Figure 7. Strategic roadmap for the sustainable development of housing and communal service objects for the period 2021-2035 (compiled by the authors). 
The short term (SR, short planning time) is from 2021 to 2024 (SR = 3 years). During this period, an ex post analysis of the city's housing and communal service facilities is carried out (see Figure 5). The medium term (MR, medium planning time) is the period from 2021 to 2027 (MR = 6 years). During this period, an ex ante analysis of the city's housing and communal service facilities is carried out (see Figure 5). The long-term period (LR, long-term planning time) is the period from 2021 to 2035 (LR = 14 years). During this period, foresight analysis or foresight forecast is carried out for the city's housing and communal service facilities (see Figure 5).

The final stage of the database formation process for the creation of a strategy for the sustainable development of housing and communal service facilities of the municipal economy was the stage of forming "living" databases of housing and communal services, which, in fact, will represent in the long-term structured datasets of small, medium, and large volumes: big data of housing and communal service objects, middle data of housing and communal service objects, and small data of housing and communal service objects (Figure 6 stage 7, Figure 7).

The detailing of the process of forming a database for the housing and communal service objects of the municipal economy is the basis for the "road map" formation based on the accounting principle for the forms of capital construction objects' reproduction.

However, the development of the "road map", in addition to considering the targets of sustainable development and determining the time perspectives for the creation of the database, takes place using end-to-end digital technologies. Starting from 2024, for effective interaction in relation to the housing and communal service facilities of the authorities, citizens and partner structures, it is planned to create digital models of housing and communal service facilities based on high-quality databases for all of the groups of housing and communal service facilities of the Russian Federation (Base NCCO $=\{\mathrm{INi}\}$; Base $\mathrm{ECCO}=\{\mathrm{IEk}\}$; Base DCCO $=\{\mathrm{IDg}\})$, which in the long term are modified using big data of housing and communal service objects, controlled by artificial intelligence.

Thus, the consolidation of modern methods of strategic analysis, methods for the assessment of the state of urban agglomerations, modern digital technologies, and infographic modeling made it possible to determine the criteria for the sustainable development of housing and communal service facilities, and to create a roadmap for their sustainable development strategy for the long term.

\section{Discussion}

Obviously, the identical management tool, all of the other things being equal, will work with different efficiency in different cities at different development levels, and will affect the urban infrastructure sustainability in different ways. Therefore, for the optimal effective implementation of the proposed initiatives ("road map"), the task of developing a methodology for the assessment of the level of urban development, including the construction of an indicator system that allows one to draw practical conclusions in terms of the adjustment of state and municipal policies, becomes relevant.

The effectiveness indicators for the implementation of the proposed "road map" can be considered absolutely achieved if, at the same time, we use a city or urban agglomeration, characterized, for example, by the list of parameters proposed in $[115,116]$ (see Table 2).

An important condition in the formation of such a parameter list is to consider the effect of using the proposed tools for various stakeholder's groups. The most popular approach involves the assessment of the effect obtained in four directions: the economic effect, the social effect, the technological effect, and the environmental effect [31]. The authors' vision of these effects for the main stakeholder groups is shown in Table 3. 
Table 2. Parameters of the investment attractiveness of the municipality [115].

\begin{tabular}{|c|c|}
\hline Factors & Parameters \\
\hline Geographical position & Profitable \\
\hline Provision of natural resources and their availability & $\begin{array}{l}\text { The level of natural resource endowment is high, and resources are } \\
\text { available }\end{array}$ \\
\hline State of the environment & The ecological situation is normal \\
\hline The structural diversity of the economy & The structure of the economy is adequate to market requirements \\
\hline The state and development of the market infrastructure & Infrastructure systems operate quickly and reliably \\
\hline Development of culture and education of the population & $\begin{array}{l}\text { The level of education and qualifications of the population is high and } \\
\text { there are opportunities for training in the necessary professions }\end{array}$ \\
\hline Socio-political stability & The socio-political climate is safe \\
\hline Economic stability & $\begin{array}{l}\text { Government controlled production costs are low; there is access to } \\
\text { investment capital and credit resources; assistance to foreign economic } \\
\text { activity is provided by the administration }\end{array}$ \\
\hline Interaction of governing bodies with enterprises & $\begin{array}{c}\text { Interaction between the city administration and city enterprises is } \\
\text { mutually beneficial and transparent }\end{array}$ \\
\hline Information and communication field & The level of equipment with advanced technologies is high \\
\hline Regulatory and legal environment & $\begin{array}{l}\text { The state of economic legislation and regulation does not limit the } \\
\text { development of production }\end{array}$ \\
\hline Investor incentive system & The tax system is acceptable and stable \\
\hline
\end{tabular}

Table 3. The effects from the proposed initiatives for different stakeholder groups (compiled by the authors).

\begin{tabular}{|c|c|c|c|c|}
\hline Stakeholders Groups & Economic Effect & Social Effect & Technological Effect & Environmental Impact \\
\hline $\begin{array}{c}\text { Managing organizations } \\
\text { of housing and } \\
\text { communal services }\end{array}$ & $\begin{array}{l}\text { The contracts cost } \\
\text { optimization for the } \\
\text { supply of utility bills. } \\
\text { Reducing the cost } \\
\text { of maintenance } \\
\text { and overhaul. }\end{array}$ & $\begin{array}{l}\text { Confidence growth of in } \\
\text { the management } \\
\text { organizations work of } \\
\text { housing and communal } \\
\text { services among } \\
\text { the citizens. }\end{array}$ & $\begin{array}{l}\text { Terms of work reduction } \\
\text { by service organizations } \\
\text { performance. The quality } \\
\text { of provided } \\
\text { utilities Improving. }\end{array}$ & $\begin{array}{l}\text { Increase in efficient } \\
\text { waste management } \\
\text { and consumption. }\end{array}$ \\
\hline $\begin{array}{l}\text { Urban } \\
\text { population/homeowners }\end{array}$ & $\begin{array}{l}\text { The cost of utility bills is } \\
\text { reducing or optimizing. }\end{array}$ & $\begin{array}{l}\text { Satisfaction with living } \\
\text { conditions among citizens } \\
\text { increase. Accessibility } \\
\text { barriers to many utility } \\
\text { services are decreasing. }\end{array}$ & $\begin{array}{l}\text { The procedure for } \\
\text { interaction with housing } \\
\text { and communal services } \\
\text { service organizations } \\
\text { is simplified. }\end{array}$ & $\begin{array}{l}\text { Increase in efficient } \\
\text { management of } \\
\text { consumer waste. }\end{array}$ \\
\hline Government & $\begin{array}{l}\text { The budget is growing } \\
\text { due to the reduction of } \\
\text { debts on utility bills and } \\
\text { due to the growth of } \\
\text { investment attractiveness } \\
\text { of the regions } \\
\text { for small and } \\
\text { medium-sized businesses. }\end{array}$ & $\begin{array}{l}\text { Increased confidence in } \\
\text { the government sector. A } \\
\text { dialogue is being } \\
\text { established between } \\
\text { citizens, government, } \\
\text { and business. }\end{array}$ & $\begin{array}{l}\text { The number of } \\
\text { emergencies at housing } \\
\text { and communal services } \\
\text { facilities is decreasing. }\end{array}$ & $\begin{array}{l}\text { Introduction and } \\
\text { implementation of the } \\
\text { green economy concept in } \\
\text { the regions. This concept } \\
\text { leads to improved health } \\
\text { and social justice of the } \\
\text { population, as well as to a } \\
\text { significant reduction in } \\
\text { hazardous environmental } \\
\text { impacts and to a decrease } \\
\text { in environmental deficit. }\end{array}$ \\
\hline $\begin{array}{l}\text { Digital technology } \\
\text { vendors }\end{array}$ & $\begin{array}{l}\text { The revenue and } \\
\text { capitalization of a digital } \\
\text { technology company } \\
\text { is increasing. }\end{array}$ & $\begin{array}{l}\text { The quality of citizens life } \\
\text { is improving. }\end{array}$ & $\begin{array}{l}\text { Digital technologies are } \\
\text { constantly improving. }\end{array}$ & $\begin{array}{l}\text { The pressure on natural } \\
\text { resources is reduced as } \\
\text { their use is reduced. }\end{array}$ \\
\hline
\end{tabular}


In order to clarify the processes of introducing digital technologies (hereinafter referred to as DT) into the activities of the housing and communal service managing organizations in the Russian Federation, it is necessary to systematize them. Therefore, the prospects for the development of this study are associated with a large-scale analysis of digital technologies used in world practice for the management of capital construction projects in the housing and communal service sector. The systematization of DT is supposed to be carried out according to the following criteria:

(1) Developed and applied in practice:

- cheap/expensive

- free access/limited access

- $\quad$ secure for the storage of private data/vulnerable for the storage of private data

- $\quad$ easy to implement/difficult to implement

- $\quad$ easy to use/difficult to use

(2) Developed, but not applied in practice:

- cheap/expensive

- free access/limited access

- $\quad$ secure for the storage of private data/vulnerable for the storage of private data

- $\quad$ easy to implement/difficult to implement

- $\quad$ easy to use/difficult to use.

Carrying out the systematization of DT will allow the most correct determination of the periods and the sequence of their implementation, and will assess the effect of their use for the main stakeholders of this process.

\section{Conclusions}

As a result of the research carried out by the authors, a strategic roadmap for the sustainable development of housing and communal service facilities was proposed, considered from the aspect of ensuring (forming) a comfortable living environment for citizens. In the authors' roadmap, management initiatives were formed for practical use by state and municipal authorities on the main reproduction forms of capital construction objects of housing and communal services. The authors considered each form of reproduction for residential buildings and structures, and for utility networks, considering their transition from one form to another. In order to combine all of the proposed initiatives into a roadmap, the authors analyzed and selected end-to-end technologies based on artificial intelligence.

As a result, the proposed "road map" will make it possible to carry out the function of initiating and combining the organizational and institutional measures necessary to streamline and accelerate the development of housing and communal services in the city as a basic condition for the development of the post-industrial economy in Russia in the long term (for 14 years). The implementation of the "road map" should lead to the removal of restrictions and the smoothing of imbalances in the development of existing housing and communal service facilities in Russian cities and real local self-government.

The developed tool (a strategic roadmap for the sustainable development strategy) will make it possible to make operational management decisions within the framework of identified or anticipated socioeconomic problems of cities from the aspect of the strategic development of housing and communal services.

The proposed management initiatives, in the form of a strategic roadmap for the sustainable development of housing and communal services, will become the initial stage in the solution of the tasks set in the Strategy of the Scientific and Technological Development of the Russian Federation and the National Project "Housing and Urban Environment", from the aspect of the formation of an organizational and managerial mechanism for the implementation of digital hubs based on artificial intelligence. 


\begin{abstract}
Author Contributions: Conceptualization, M.P. and S.B.; methodology, M.P. and S.B.; validation, M.P. and S.B.; formal analysis, M.P. and S.B.; investigation, M.P. and S.B.; resources, M.P. and S.B.; data curation, M.P. and S.B.; writing—original draft preparation, M.P. and S.B.; writing-review and editing, M.P. and S.B.; visualization, M.P. and S.B.; supervision, M.P. and S.B.; project administration, M.P. and S.B. All authors have read and agreed to the published version of the manuscript.
\end{abstract}

Funding: This work was financially supported by the Ministry of Science and Higher Education, grant number 075-15-2021-686. All of the tests were carried out using the research equipment of The Head Regional Shared Research Facilities of the Moscow State University of Civil Engineering.

Conflicts of Interest: The authors declare no conflict of interest.

\title{
References
}

1. 17 Sustainable Development Goals Our World. UN Resolution №A70/L.1. Available online: https://www.un.org/ sustainabledevelopment/ (accessed on 8 November 2021).

2. Development Strategy of the Construction Industry and Housing and Communal Services of the Russian Federation until 2035 on 1 November 2021. Available online: http://sroportal.ru/media/V-Strategiya-na-sayt-i-GASU.pdf (accessed on 18 November 2021).

3. Yearbook of the United Nations. 1987, p. 4. Available online: https://shop.un.org/ru/node/31288 (accessed on 18 November 2021).

4. Martin, C.; Evans, J.; Karvonen, A. Smart and sustainable? Five tensions in the visions and practices of the smart-sustainable city in Europe and North America. Technol. Forecast. Soc. Chang. 2018, 133, 269-278. [CrossRef]

5. Sayenko, I.; Astafiev, S. Management of the Sphere of Housing Construction to Improve the Comfort of Living of the Population in the Formation of Projects for the Integrated Development of Territories: A Monograph; Siberian Federal University Ltd.: Krasnoyarsk, Russia, 2020; 160p.

6. Expanded Collection of WCIOM Data. Available online: https://sociodigger.ru/wp-content/uploads/2021/08/\%D0\%A0\%D0 \%B5\%D0\%B9\%D1\%82\%D0\%B8\%D0\%BD\%D0\%B3\%D0\%B8_\%D0\%92\%D0\%A6\%D0\%98\%D0\%9E\%D0\%9C.pdf (accessed on 6 November 2021).

7. Politics and Social Demands of Citizens: Data from Public Opinion Polls. Available online: https://wciom.ru/presentation/ prezentacii/ politika-i-socialnye-zaprosy-grazhdan-dannye-oprosov-obshchestvennogo-mnenija (accessed on 18 November 2021).

8. Information on the Results of a Sociological Study of Citizens' Satisfaction with the Quality and Availability of the Provision of State (Municipal) Services on the Principle of "One Window" for 2020. Available online: https://depeconom.admhmao.ru/ upload/iblock/ae7/Informatsiya-o-rezultatakh-sotsiologicheskogo-issledovaniya-udovletvorennosti-grazhdan-kachestvomi-dostupnostyu-predostavleniya-GMU__2_.pdf (accessed on 18 November 2021).

9. Federal State Statistics Service. Available online: https:/ / rosstat.gov.ru/ (accessed on 18 November 2021).

10. Sirotkin, V. Theory and Methodology of Reproduction of the Housing Stock. Ph.D. Thesis, Russian State Vocational Pedagogical University, Yekaterinburg, Russia, 2014. Available online: https:/ / elar.urfu.ru/bitstream/10995/27008/1/urfu1392s.pdf (accessed on 11 November 2021).

11. DOM.RF. Available online: https://xn--d1aqf.xn--p1ai/about/ (accessed on 18 November 2021).

12. The Russian Federation President Decree Dated 01.12.2016 No. 642 “On the Russian Federation Scientific and Technological Development Strategy". Available online: http:/ / www.kremlin.ru/acts/bank/41449 (accessed on 18 November 2021).

13. Unified Plan to Achieve the National Development Goals of the Russian Federation for the Period up to 2024 and for the Planning Period until 2030. Available online: http:/ / project.orb.ru/wp-content/uploads /2020/09/\%D0\%95\%D0\%B4\%D0\%B8\%D0\%BD\% D1\%8B \%D0\%B8_- \%D0\%BF\%D0\%BB\%D0\%B0\%D0\%BD-\%D0\%BF\%D1\%80\%D0\%BE\%D0\%B5\%D0\%BA\%D1\%82-\%D0\%BD \% D0\%B0-20.08.pdf (accessed on 18 November 2021).

14. Provision of Affordable and Comfortable Housing and Utilities for Citizens of the Russian Federation in 2020. Available online: https: / ach.gov.ru/upload/iblock/663/663d14307b8256f367401b391d239e43.pdf (accessed on 11 November 2021).

15. On the Results on 2020 and Strategic Plans of the Construction Ministry. Available online: https://www.minstroyrf.gov.ru/ (accessed on 11 November 2021).

16. Report on the Implementation of the Construction Ministry Action Plan, Housing and Utilities of the Russian Federation for 2020 dated 03 March 2021. Available online: https://www.minstroy.saratov.gov.ru/ministry/collegia/?SECTION_ID=406 (accessed on 18 November 2021).

17. Comprehensive Assessment of Investment Attractiveness the Multi-Storey Residential Real Estate Market. Available online: https:/ / macon-realty.ru/files/uploaded/docs/1d9fa0f1-4727-4a7d-90bc-9fe0c14962ed.pdf (accessed on 18 November 2021).

18. BREEAM Ltd. Available online: https:/ / www.breeam.com/ (accessed on 18 November 2021).

19. Ecovillage Ltd. Available online: http:/ / www.ecovillage.ru/sense.php (accessed on 18 November 2021).

20. The Russian Federation Government Order the of November 30, 2010 No. 2136-r On Approval the Concept for Sustainable Development of the Russian Federation Rural Areas for the Period until 2020. Available online: https://www.garant.ru/ products/ipo/prime/doc/2073544/ (accessed on 18 November 2021). 
21. Kovalev, A.S. Instruments of State Management in the Sphere of Housing and Communal Services of the Russian Federation. State Registration 2019. Available online: http://gosreg.amchs.ru/pdffiles/27number/articles/Kovalev-27.pdf (accessed on 8 December 2021).

22. Bobrovskaya, N.I.; Kuzina, S.I. Public Police Strategies in Housing and Utilities Sector. Management Issues 2014, 31-37. Available online: https:/ / cyberleninka.ru/article/n/strategii-gosudarstvennoy-politiki-v-sfere-zhilischno-kommunalnogo-hozyaystvas-uchetom-zarubezhnogo-opyta/viewer (accessed on 18 November 2021).

23. Fattakhov, R.V.; Nizamutdinov, M.M. Methodological aspects of assessing the performance of regional authorities in the management of housing and communal services. Adm. Sci. 2016, 6, 67-97.

24. Federal Law of 21.07.2014 No. 209-FZ (as amended on 31.12.2017) “On the State Information System of Housing and Communal Services" (as Amended and Supplemented, Entered into Force on 01.03.2018). Available online: http://www.consultant.ru/ document/cons_doc_LAW_165810/(accessed on 8 December 2021).

25. Bramley, G.; Dempsey, N.; Power, S.; Brown, C.; Watkins, D. Social sustainability and urban form: Evidence from five British cities. Environ. Plan. 2009, 41, 2125-2142. [CrossRef]

26. Capgemini Research Institute Intelligent Automation in Energy and Utilities Survey. 2019. Available online: https://www. capgemini.com/wp-content/uploads/2019/05/Digital-Report-\%E2\%80\%93-Automation-in-Utilities-1.pdf (accessed on 8 December 2021).

27. City of Kloten. Report on the Local Housing Situation, Municipal Planning Authority on Behalf of the City Council; City of Kloten: Kloten, Switzerland, 2020; pp. 1-12.

28. Kumar, T.K.-S.; Weiss, S.D. The cooperative urban land development model in Germany-An effective instrument to support affordable housing. Land Use Policy 2021, 107, 105481.

29. Debrunner, G.; Hartmann, T. Strategic use of land policy instruments for affordable housing-Coping with social challenges under scarce land conditions in Swiss cities. Land Use Policy 2020, 99, 104993. [CrossRef]

30. Gecíková, I.; Papcunová, V. Using of Strategic Management Tools in Conditions of Local Self-Government in Slovakia. Procedia Soc. Behav. Sci. 2014, 110, 969-978. [CrossRef]

31. Malik, S.; Tariq, F. Recasting paradigms of institutional analysis and stakeholder analysis in housing research. J. Urban Manag. 2021, 10, 357-368. [CrossRef]

32. Balmer, J.D.; Gerber, J.D. Why are housing cooperatives successful? Insights from Swiss affordable housing policy. Hous. Stud. 2017, 33, 361-385. [CrossRef]

33. Mark Lee, M.; Rueda-Benavides, J.A.; Gransberg, D.D. Utility Management System Cost and Time Benefits and Implications from the Local Agency Perspective. Available online: https://www.researchgate.net/publication/281909968_Utility_Management_ System_Cost_and_Time_Benefits_and_Implications_from_the_Local_Agency_Perspective (accessed on 18 November 2021).

34. Aalbers, M.B. The Variegated Financialization of Housing. Available online: https:// doi.org/10.1111/1468-2427.12522 (accessed on 18 November 2021).

35. Batra, R. A thematic analysis to identify barriers, gaps, and challenges for the implementation of public-private-partnerships in housing. Habitat Int. 2021, 118, 102454. [CrossRef]

36. Chen, J.; Wu, F. Housing and land financialization under the state ownership of land in China. Land Use Policy 2020, 112, 104844 [CrossRef]

37. Yakubu, I. From a cluster of villages to a city: Housing politics and the dilemmas of spatial planning in Tamale, Ghana. Land Use Policy 2021, 109, 105668. [CrossRef]

38. Fangzhu, Z.Y.; Zhu, Z.Z. China's urban construction investment bond: Contextualizing a financial tool for local government. Land Use Policy 2020, 122, 105153.

39. Anja, A.L.; Kharoubi, K.C. Management accounting systems in institutional complexity: Hysteresis and boundaries of practices in social housing. Manag. Account. Res. 2020, 49, 100715.

40. HilbertIan, M.; Othmer, M.J. Foresight tools for participative policy-making in inter-governmental processes in developing countries: Lessons learned from the eLAC Policy Priorities Delphi. Technol. Forecast. Soc. Chang. 2009, 76, 880-896. [CrossRef]

41. Romano, B. Environmental Fragmentation Tendency: The Sprawl Index. Available online: https://www.econstor.eu/bitstream/ 10419/117173/1/ERSA2004_441.pdf (accessed on 18 November 2021).

42. The Conference of the Parties. Decision CP.15. The Copenhagen Accord of 18 December 2009. Available online: http://unfccc int/files/meetings/cop_15/application/pdf/cop15_cph_auv.pdf (accessed on 18 November 2021).

43. Doing Business 2019. Training for Reform. Available online: https://www.worldbank.org/content/dam/doingBusiness/media/ Annual-Reports/English/DB2019-report_web-version.pdf (accessed on 18 November 2021).

44. Rating Doing Business 2020. Available online: https://documents1.worldbank.org/curated/en/688761571934946384/pdf/ Doing-Business-2020-Comparing-Business-Regulation-in-190-Economies.pdf (accessed on 18 November 2021).

45. Total to develop artificial intelligence solutions with Google Cloud. Total Energies ADR, 24 April 2018.

46. AI in the utility, energy industries making the power grid the information grid. The Business and Technology of Enterprise AI, 27 July 2017.

47. United Utilities' RPA crack team makes early gains. Computer Weekly, 11 March 2019.

48. How is Data Supporting Renewable Integration? VELCO Demonstrates; Engerati: London, UK, 2017. 
49. Development Trends of Artificial Intelligence in the Sphere of Utilities (Analytical Review), Moscow, Russia, August 2020. Available online: https:/ /innoagency.ru/files/AI_Utilities_AIM_August\%202020.pdf (accessed on 8 December 2021).

50. FORUM. Digital Smart City 2021. Available online: http://www.eu-smartcities.eu (accessed on 18 November 2021 ).

51. Smartcitysweden Ltd. Available online: https:/ / smartcitysweden.com/focus-areas / (accessed on 18 November 2021).

52. Innopolis Forum. Available online: http://innopolis.ru/city/history/ (accessed on 18 November 2021).

53. Assessing Results of the Digital Transformation Effectiveness the Urban Economy of the Russian Federation (IQ CITIES). Available online: https:/ / d-russia.ru/wp-content/uploads/2021/10/list-s-gorodami-iq-final.pdf (accessed on 8 November 2021).

54. Stankevich, A. Intelligent Systems and Technologies; Yurayt Publishing House Ltd.: Moscow, Russia, 2019; 397p.

55. Gusarova, N.; Dobrenko, N. Intelligent Systems and Technologies; ITMO University Ltd.: St. Petersburg, Russia, 2019; 55p.

56. Ostroukh, A.; Surkova, N. Intelligent Information Systems and Technologies: Monograph; Research and Innovation Center Ltd.: Krasnoyarsk, Russia, 2015; 370p, Available online: http:/ /lib.madi.ru/fel/fel1/fel16S062.pdf (accessed on 18 November 2021).

57. Limonov, L.E. Urbanistics. In Urban Economy, Development and Management: Textbook and Workshop for Universities; Limonov, L.E., Ed.; Yurayt Publishing House, Ltd.: Moscow, Russia, 2020; pp. 59-168.

58. Baloyan, B.M.; Guitarsky, M.L. Geourbanistics: A Textbook for Universities; Yurayt Publishing House, Ltd.: Moscow, Russia, 2021; pp. 77-92.

59. Puzanov, A.; Popov, R. Approaches to Assessing the Development of Urban Agglomerations. Available online: https:// urbaneconomics.ru/sites/default/files/iue_press.pdf (accessed on 11 November 2021).

60. Uchida, H.; Nelson, A. Agglomeration Index: Towards a New Measure of Urban Concentration, Working Paper; World Institute for Development Economics Research: Kingston, NY, USA, 2010; p. 29

61. Prakash, M.; Teksoz, K.; Espey, J.; Sachs, J.; Shank, M.; Schmidt-Traub, G. Achieving a Sustainable Urban America. The U.S. Cities Sustainable Development Goals Index. 2017. Available online: http://unsdsn.org/wp-content/uploads/2017/08/US-CitiesSDG-Index-2017.pdf (accessed on 18 November 2021).

62. Sassen, S. Cities in Word Economy; Thousand Oaks SAGE Publications: New York, NY, USA, 2018.

63. Storper, M.; Kemeny, T.; Makarem, N.P.; Osman, T. The Rise and Fall of Urban Economies: Lessons From San Francisco and Los Angeles; Stanford University Press: Stanford, CA, USA, 2005; 328p, Available online: https://www.researchgate.net/publication/305491 543_Book_Review_of_the_Rise_and_Fall_of_Urban_Economies_by_Michael_Storper_Thomas_Kemeny_Naji_Makarem_and_ Taner_Osman_Stanford_University_Press_2015 (accessed on 18 November 2021).

64. Pütz, T. Empirische Zusammenschau der Europäischen Metropolregionen in Deutschland// nformationen zur Raumentwicklung Heft 5.2016, Bundesinstitut für Bau-, Stadt- und Raumforschung. Available online: https:/ / www.forschungsinformationssystem. de/servlet/is/485946/ (accessed on 18 November 2021).

65. U.S. Cities SDG Index 2019. Available online: https://sdgindex.org/reports/2019-us-cities-sustainable-development-report/ (accessed on 18 November 2021).

66. U.S. Cities SDG Index 2018. Available online: https://sdgindex.org/reports/2018-u.s.-cities-sdgs-index/ (accessed on 18 November 2021).

67. U.S. Cities SDG Index 2017. Available online: https://sdgindex.org/reports/2017-u.s.-cities-sdg-index/US-Cities-SDG-Index-20 17.pdf (accessed on 18 November 2021).

68. Rigatti, D. Measuring Conurbation. In Proceedings of the 7th International Space Syntax Symposium, Stockholm, Sweden, 2009; Available online: http:/ / www.sss7.org/Proceedings/05\%20Spatial\%20Morphology\%20and\%20Urban\%20Growth/093_Rigatti. pdf (accessed on 11 November 2021).

69. Urban Indicators Guidelines. UN-HABITAT. Available online: https:/ / data.unhabitat.org/ (accessed on 18 November 2021).

70. Glazychev, V.; Starodubrovskaya, I. Chelyabinsk Agglomeration: Development Potential; SUSU Publishing: Chelyabinsk, Russia, 2008; 278p.

71. Chulkov, V.; Chulkov, G. System Engineering and the Systemology of Infographies. Parts 1 and 2; International Inter-Academic Union Ltd.: Moscow, Russia, 1999.

72. Chulkov, V.O.; Kazaryan, R.R.; Levin, B.A. Infographic Modeling in Anthropotechnical Management; Chulkov, V., Ed.; SvR-ARGUS: Moscow, Russia, 2017; 920p.

73. Chulkov, V.; Rakov, V. Infographies of Functional Systems. Chapter III. Information Models of Functional Systems; Sudakova, K., Ed.; The New Millennium Foundation Ltd.: Moscow, Russia, 2004; pp. 55-82.

74. Phillips-Wren, G. Intelligent Decision Support Systems. Available online: https://www.researchgate.net/publication/27770350 2_Intelligent_Decision_Support_Systems (accessed on 11 November 2021).

75. Lika, R. Robo-revolution: A Marxist approach to social uprising in the high-tech age. Sociol. Rev. 2019, 18, 224-244.

76. Brooks, R. The Seven Deadly Sins of AI Predictions. MIT Technology Review, 6 October 2017.

77. Canadian Utility Pilots AI and Analytics to Reduce Leaks by 60\%. Smart Energy International, 28 November 2018.

78. Utilities and Machine Learning - The Use Cases; Engerati: London, UK, 2018.

79. Shabanov, R.; Mikushin, N. Intelligent Information System for Decision Support. Young Res. Don 2019, 4, 91-97. Available online: https:/ / cyberleninka.ru/article/n/intellektualnaya-informatsionnaya-sistema-podderzhki-prinyatiya-reshenii/viewer (accessed on 11 November 2021).

80. Ostroukh, A. Intelligent Systems: Monograph; Research and Innovation Center Ltd.: Krasnoyarsk, Russia, 2020; 316p, Available online: http:/ /nkras.ru/arhiv/2020/ostroukh2.pdf (accessed on 18 November 2021). 
81. Artificial Intelligence to Control the Power Grid in Riedholz; Landisgyr: Cham, Switzerland, 2016.

82. Rapid ROI from RPA: Synergy Automates Billing to Realize Significant Value. Automation Anywhere, 1 July 2018.

83. Turner, J. The Handbook of Project-Based Management: Improving the Processes for Achieving Strategic Objectives. Available online: https://www.researchgate.net/publication/243765723_The_Handbook_of_Project-Based_Management (accessed on 18 November 2021).

84. Mercer: Featured Report. Sustainable Investment Declaration. Available online: https://www.mercer.com/ (accessed on 18 November 2021).

85. Gow, G. Environmental Sustainability and AI. Available online: https://www.forbes.com/sites/glenngow/2020/08/21 / environmental-sustainability-and-ai/?sh=2e56890c7db3 (accessed on 11 November 2021).

86. How Utility CIOs can Best Plan for Artificial Intelligence; Gartner: Stanford, CA, USA, 2018.

87. Upskilling Your People for the Age of the Machine; Capgemini Research Institute: Paris, France, 2018.

88. Weili, T. Research on the Social Impact of Artificial Intelligence and Government's Coping Strategies. Manag. Consult. 2020, 7, 114-123. Available online: https:// cyberleninka.ru/article/n/research-on-the-social-impact-of-artificial-intelligence-andgovernment-s-coping-strategies (accessed on 18 November 2021).

89. Ding, J. Case Investigation Technology Based on Artificial Intelligence Data Processing. Hindawi J. Sens. 2021, 4942657. Available online: https:/ / downloads.hindawi.com/journals/js/2021/4942657.pdf (accessed on 19 November 2021).

90. Soto-Acosta, P.; Popa, S.; Martinez-Conesa, I. Information Technology, Knowledge Management and Environmental Dynamism as Drivers of Innovation Ambidexterity: A Study in SMEs. Emerald Publation Ltd. Knowl. Manag. 2018, 22, 931-948.

91. Turning Big Data into Clean Electrons at NextEra; Harvard Business School Digital Initiative: Boston, MA, USA, 2018.

92. New SMART Procurement Platform; Exxon Mobil: Moscow, Russia, 2018.

93. Exelon's Customer Connections Extend beyond Power Lines and into Chatbots; Oracle: San Francisco, CA, USA, 2017.

94. Berg, S.V.; Phillips, M.A. Data availability as a key tool for regulating government-owned water utilities. Util. Policy 2017, 49, 30-37. [CrossRef]

95. Muczyński, A.; Zwirowicz-Rutkowska, A.; Źróbek, R. The information system for social housing management as a part of the land administration system-A case study of Poland. Land Use Policy 2019, 86, 165-176. [CrossRef]

96. Pronin, C.; Ostroukh, A.; Pronin, B.; Vasiliev, Y.; Kotliarskiy, E. Development of a quantum algorithm based on quantum parallelism for finding the shortest path in a graph. ARPN J. Eng. Appl. Sci. 2019, 14, 848-851.

97. Ostroukh, A.; Vakhrushev, O.; Maikov, K.; Kolbasin, A. Combined identification method by reconstruction and analysis of face 3D structure. ARPN J. Eng. Appl. Sci. 2019, 14, 1385-1388.

98. Ostroukh, A.; Vasiliev, Y.; Kotliarskiy, E.; Sarychev, I. Connected Quarry Machines Digital Systems. ARPN J. Eng. Appl. Sci. 2019, $14,135-140$.

99. Arbuzov, V.; Ivchenko, V.; Matiukhina, E.; Pavelyev, S.; Ostroukh, A. Application of neural network technologies for diagnostics of the technical state of power plant turbo generators based on spectrograms of the vibration. Meas. ARPN J. Eng. Appl. Sci. 2018, 13, 2549-2555.

100. How BP Drives Automation at Scale across Supply and Trading Business. Computer World, 22 June 2018.

101. John, C.; Bertot, J.C.; Jaeger, P.T.; Grimes, J.M. Using ICTs to create a culture of transparency: E-government and social media as openness and anti-corruption tools for societies. Gov. Inf. Q. 2010, 27, 264-271.

102. Gasova, K.; Stofkova, K. E-Government as a Quality Improvement Tool for Citizens' Services. Procedia Eng. 2017, 192, 225-230. [CrossRef]

103. Xcel Energy Utilizing Machine Learning to Efficiently and Reliably Incorporate Renewable Energy into the US Energy Grid; Harvard Business School Digital Initiative: Boston, MA, USA, 2018.

104. California Sets Goal of 100 Percent Renewable Electric Power by 2045; NPR: Washington, DC, USA, 2018.

105. Managing Talent to Address Energy Challenges. Shell, Media, Speeches \& Articles, 14 March 2013. Available online: https: //www.shell.com/media/speeches-and-articles/2013/managing-talent-to-address-energy-challenges.html (accessed on 8 December 2021).

106. Li, C.Z.; Chen, Z.; Zhao, Y. A blockchain- and IoT-based smart product-service system for the sustainability of prefabricated housing construction. J. Clean. Prod. 2020, 286, 125391. [CrossRef]

107. Murchie, J.; Pang, J.; Schwegman, D.J. Can information help Lakisha and Jamal find housing? Evidence from a low-cost online experiment of landlords. Reg. Sci. Urban Econ. 2021, 90, 103712. [CrossRef]

108. Muczyński, A.; Zwirowicz-Rutkowska, A.; Nowak da Costa, J. Supporting tenant relocation in social housing management: Development of the dedicated geoinformation system in Poland. Cities 2021, 120, 103431. [CrossRef]

109. Urban Planning Code of the Russian Federation of December 29, 2004 N 190-FZ (as amended on 27 December 272019 ) Article 1. (As Amended by the Federal Law of 08/03/2018 N 342-FZ). Available online: http:/ /www.consultant.ru/document/cons_doc_ LAW_51040/(accessed on 8 December 2021).

110. Accounts Chamber Bulletin of the Russian Federation. Sustainable Development Goals. Available online: https://ach.gov.ru/ upload/iblock/b06/b065c140de24fbc32271bb2267f621ec.pdf (accessed on 18 November 2021).

111. Monitoring of the Sustainable Development Goals Indicators the Russian Federation for 2017. Available online: https://www. gks.ru/publish/cur/s1/egorenko.pdf (accessed on 6 November 2021).

112. Price Waterhouse Coopers. Available online: https:/ / www.pwc.com/ (accessed on 18 November 2021). 
113. 15th Annual Demographia International Housing Affordability Survey: 2010. Available online: http://www.demographia.com/ dhi2019.pdf (accessed on 18 November 2021).

114. Order of the State Committee on Architecture of 11/23/1988 N 312 “On the Approval of Departmental Building Codes of the State Committee on Architecture. Available online: https://gzhi.mosreg.ru/dokumenty/normotvorchestvo/zakonodatelstvo-vsfere-zhkh/11-06-2020-15-41-56-prikaz-goskomarkhitektury-ot-23-11-1988-n-312-ob-u (accessed on 8 December 2021).

115. Zyumalina, A. Investment Attractiveness of the City: Concept, Definitions, Assessment Methods. Young Sci. 2011, 8, $133-137$. Available online: https:/ / moluch.ru/archive/31/3531/ (accessed on 6 November 2021).

116. Razuvaev, V. Assessment of investment attractiveness of regions of the Russian Federation, Perm, Russia. Bull. Perm Univ. 2011, 3 , 45-53. Available online: http:/ / econom.psu.ru/upload/iblock/3dd/razuvaev-v.v.-otsenka-investitsionnoy-privlekatelnostiregionov-rossiyskoy-federatsii.pdf/ (accessed on 6 November 2021). 